\title{
USE OF REFURBISHED SHIPPING CONTAINERS FOR THE CONSTRUCTION OF HOUSING BUILDINGS: DETAILS FOR THE STRUCTURAL PROJECT
}

\author{
Luís F. A. BERNARDO, Luiz A. P. OLIVEIRA, Miguel C. S. NEPOMUCENO, \\ Jorge M. A. ANDRADE \\ Department of Civil Engineering and Architecture, University of Beira Interior, \\ 6201-001 Covilhã, Portugal
}

Received 31 May 2011; accepted 14 Dec. 2011

\begin{abstract}
Construction using refurbished shipping containers is a recent building system, with already many successful examples around the world. This system presents a huge potential in the field of sustainable construction provided by the recycling of used containers. This paper aims to contribute to a better knowledge of this construction system in what concerns to the structural project. The general constitution of two maritime shipping containers is presented as well as some aspects of their structural behavior. For this purpose, numerical analyses were performed using a finite elements analysis program. Normative aspects for the structural project are also presented. This paper also presents the analysis of a case study with the use of refurbished shipping containers to build a single-family house. The evaluation of the strength of the refurbished shipping containers to building actions is carried out. It is shown that such evaluation is not easy because some mechanical parameters of noncommercial steel section of the elements that compose the shipping containers are unknown. Nevertheless, this study shows the feasibility of this building system.
\end{abstract}

Keywords: construction system; shipping containers; structural behavior; finite elements analysis; case study.

Reference to this paper should be made as follows: Bernardo, L. F. A.; Oliveira, L. A. P.; Nepomuceno, M. C. S.; Andrade, J. M. A. 2013. Use of refurbished shipping containers for the construction of housing buildings: details for the structural project, Journal of Civil Engineering and Management 19(5): 628-646.

http://dx.doi.org/10.3846/13923730.2013.795185

\section{Introduction}

The economic recession period that we are currently passing by, especially in Europe, as leaded to a significant reduction in the exchange of goods by sea. Consequently, the accumulation of shipping containers at seaports, mainly in importing countries, has increased. This has led to problems of space allocation (Pisinger 2002). This was one of the reasons that have triggered the start of use containers for the construction of housing buildings. In a generalized panorama of economic crisis, construction based on the reuse of shipping containers can represent a new important market niche.

Containers are designed to carry and bear very high loads, as well as resist to aggressive environments during a lifetime of 15 years or more (Nunes 2009). For example, one of the requirements imposed by ISO norms is that the containers should be able to support at least other six containers over with maximum load (ISBU 2009). Among different types of containers existing on the market, special attention should be given to the containers manufactured in accordance with ISO norms, which ensure uniformity in what concerns to their mechanical and geometrical characteristics.

In the market, there are shipping containers with several external dimensions. The most common ones have lengths with $6.0,9.0$, and $12.0 \mathrm{~m}$ and heights with 2.4, 2.55 , and $2.7 \mathrm{~m}$. The width is usually $2.4 \mathrm{~m}$. For housing buildings the most commonly used containers have 6.0 and $12.0 \mathrm{~m}$ long and $2.7 \mathrm{~m}$ high because it provides a bigger ceiling height. Such containers are called HC (High Cube), with commercial names as $20^{\prime} \mathrm{HC}(6.0 \mathrm{~m}$ or 20 feet long) and $40^{\prime} \mathrm{HC}$ ( $12.0 \mathrm{~m}$ or 40 feet long).

The main structure elements of the shipping containers are made of steel. They incorporate trapezoidal metal sheets to form the walls and roof and profiles to form the "box" edges and the grid to support the wooden floor. The corners have rigid pieces to support the container and to allow the connection between containers. The door is located in one of the smaller faces. 
By using old shipping containers, this construction system contributes for the recycling and construction sustainability (Vijayalaxmi 2010; Lun 2011). Many constructions based on the use of shipping containers already exist all over the world in many countries for over a decade (South Africa, Australia, USA, Holland, Japan, New Zealand, and UK, among other, as reported by Webb 2006; Murdock 2009; Nunes 2009). Most of those constructions are housing buildings, such as single-family and multi-family buildings, residence halls or dormitories. Many examples can be found in architectural literature and websites. Also buildings with other functions, particularly for commercial, hotel, tourist, business and public sectors, such as offices, corporate offices, studios for artists, restaurants, cafes, hotels, apartment hotels as well as museums and schools constitute other possible cases to use this construction system. However, costumers and promoters still fear this new construction system in many countries, namely in Portugal.

The remodeling process of the containers should be held in factories to guarantee quality control. This phase includes all the preparatory works such as disinfection and cleaning, openings, strengthenings, connections, surface preparation, painting and, eventually, also the implementation of installation networks. To guarantee the success of this phase, project must include all necessary details for the preparation of the containers, in order that no problems occur in the construction site during assembly. In the final phase, containers are transported to the construction site to be positioned and connected.

\section{Relevance of the subject}

Papers focused on the structural field of buildings construction system with the use of refurbished shipping containers are rare. Most of the existing literature focuses mainly on architectural aspects. This paper intends to contribute to a better understanding of this construction system. Structural behavior and some elements for the civil engineering project are focused in this paper.

\section{Description of containers $20^{\prime} \mathrm{HC}$ and $40^{\prime} \mathrm{HC}$}

\subsection{General characteristics}

The following list includes important ISO norms for shipping containers to be consulted by the engineer:

- ISO 1496-1:1990 - Series 1 - Container shipping. Specification and testing - Part 1: Containers for marine applications in use;

- ISO 668:1995 - Series 1 - Container shipping. Classification, dimensions and calculations;
- ISO 3874:1997- Series 1 - Container shipping. Handling and safety;

- ISO 830:1999 - Freight containers - Vocabulary.

\subsection{General characteristics}

The containers analyzed in this study are designated by ISO as 1AAA and 1CCC, also known at the market as models $20^{\prime} \mathrm{HC}$ and $40^{\prime} \mathrm{HC}$ (Fig. 1), respectively. The height of those containers $(2.71 \mathrm{~m})$ enables a minimum clear ceiling height of $2.40 \mathrm{~m}$. This value respects the minimum required by many national codes for the construction of housing buildings. Table 1 presents the main characteristics of the containers.

As illustrated in Figure 2, the containers are composed by the front face (1), the face of the door (2), two sides (3), roof (4), and the base structure (5).

The containers are composed with several elements (Fig. 2, Tables 2 and 3), including several steel profiles to form steel frames. The front and side walls include trapezoidal sheets (cold formed) with vertical ribs and thickness ranging between 1.6 and $2.0 \mathrm{~mm}$. The roof is made with trapezoidal sheets (pressed) with ribs. The doors, made of two leaves, are composed by a frame and sheets. The leaves are connected to the gate of the container with two hinges. Almost all profiles are made of cold-formed steel sections, with steel plates whose thickness varies between 4.0 and $6.0 \mathrm{~mm}$.

The floor is in plywood (thickness $28 \mathrm{~mm}$ ) supported by a steel grid, which constitute the base structure. This structure is formed of several cross members (BCM) and two bottom side rails (RDB). For handling, containers include opening fork pocket (FP).

The front face is composed by two trapezoidal sheets (front end wall - few) jointed through automatic welding to form a panel welded to a frame which is constituted of several profiles: an upper front header $(\mathrm{FH})$, a lower square steel tube (front sill FS), two vertical corner posts (FCP) and four corner pieces.

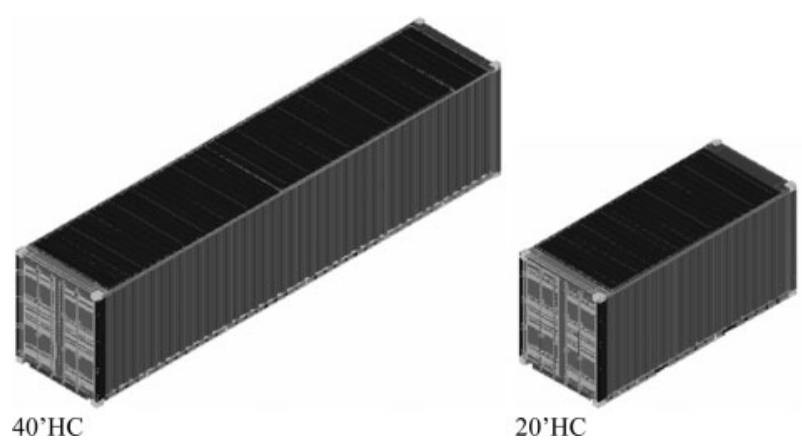

Fig. 1. Containers $20^{\prime} \mathrm{HC}$ and $40^{\prime} \mathrm{HC}$ 
Table 1. Characteristics of containers 20'HC and 40' $\mathrm{HC}$

\begin{tabular}{|c|c|c|c|c|c|c|c|}
\hline \multirow[b]{2}{*}{ Model } & \multirow{2}{*}{$\begin{array}{c}\text { Length }(\mathrm{m}) \text {, } \\
\text { internal/external }\end{array}$} & \multirow{2}{*}{$\begin{array}{l}\text { Width }(\mathrm{m}) \text {, } \\
\text { internal/external }\end{array}$} & \multirow{2}{*}{$\begin{array}{c}\operatorname{High}(\mathrm{m}), \\
\text { internal/external }\end{array}$} & \multirow[b]{2}{*}{ Self-weight (kg) } & \multicolumn{2}{|c|}{ Load capacity } & \multirow{2}{*}{$\begin{array}{c}\text { Capacity } \\
\text { Volume }\left(\mathrm{m}^{3}\right)\end{array}$} \\
\hline & & & & & Total (kg) & Surf. $\left(\mathrm{kg} / \mathrm{m}^{2}\right)$ & \\
\hline $20{ }^{\prime} \mathrm{HC}$ & $5.9 / 6.0$ & $2.34 / 2.40$ & $2.71 / 2.89$ & 2300 & 28,000 & 867.63 & 37.41 \\
\hline $40^{\prime} \mathrm{HC}$ & $12.0 / 12.2$ & $2.34 / 2.40$ & $2.71 / 2.89$ & 2300 & 36,000 & 1229.51 & 76.10 \\
\hline
\end{tabular}

The door face is composed by one frame which includes a lower door sill (DS) made with a channel section, two vertical corner posts (DCP) built with a channel shape in hot-rolled steel and another one in cold-formed steel welded together to form a hollow section, an upper door header (DH) composed by an inner "U" and an outer shape made of cold-formed steel welded together to form a hollow section, four corner pieces and secondary elements of the door locking devices.

Each door leaf includes a sheet welded to a frame with a locking device, two hinges, seals, and supports. The doors are usually removed and used as secondary elements of construction; therefore, they are neither described in detail nor considered as main structural elements in this paper.

The lateral faces are composed with an upper square steel tube (top side rail - TSR) and the side wall (sw) composed of several trapezoidal sheets held together by welding. For model $40^{\prime} \mathrm{HC}$, the thicker sheets (external) were designated by sw $1 / \mathrm{sw} 3$, while less thick sheets (internal) by sw2. For model $20^{\prime} \mathrm{HC}$, external and internal sheets were designated by sw1 and sw2, respectively.

The roof consists of pressed steel sheets joined by automatic welding. Such sheets are generally not considered as structural element once ribs don't exists near the top side rail.

Containers also include many local strengthening plates. The joints between the several elements that compose the containers are made by continuous welding.

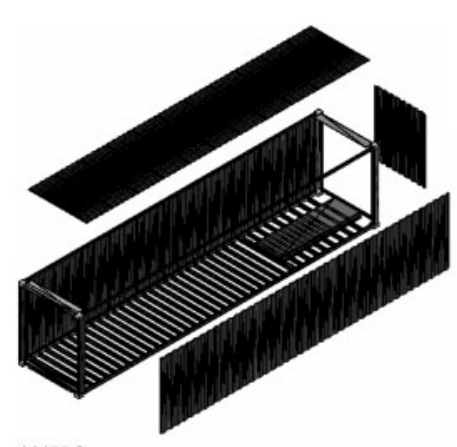

$40{ }^{\prime} \mathrm{HC}$

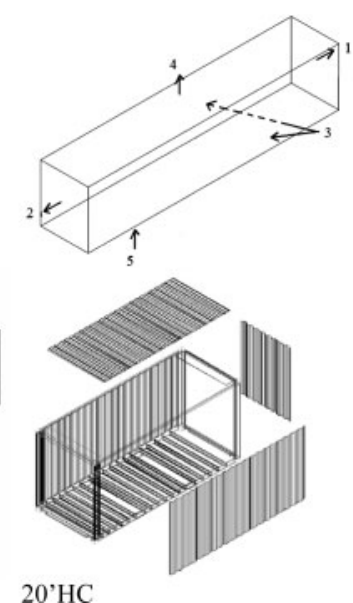

20'HC
Fig. 2. Containers composition
Based on this section, we can conclude that the constitution of a shipping container is very complex. Most of the elements are made of profiles with noncommercial sections. The terminology used in this section to designate many elements follows ISO norms for container vocabulary.

\subsection{Materials}

Corten A steel compose most of the components of the containers. Only profile DCP is made with steel SM50YA. The characteristic values of the yielding stress $\left(f_{y k}\right)$ are $343 \mathrm{MPa}$ (Corten A) and $363 \mathrm{MPa}$ (SM50YA).

\section{Evaluation of prevailing forces in containers}

The evaluation of the prevailing forces in the elements of the containers, in order to apply normative criteria's (Section 4), was accomplished with an elastic analysis of the containers under typified loading. To achieve this goal, numerical models were implemented through the finite element analysis software LUSAS (2010).

The spatial geometry of the containers was defined taking into account the location of the steel profiles axes. The linear elements were modeled with linear finite elements (thick beam) with linear interpolation. For each element, the geometrical properties of the gross section were introduced. Such properties were calculated manually. Table 4 present the most relevant geometrical properties of the gross section of the elements, namely area $(A)$, moments of inertia $\left(I_{y}\right.$ and $\left.I_{z}\right)$, and shear areas $\left(A_{s y}\right.$ and $\left.A_{s z}\right)$ with respect to the coordinate axes $y$ and $z$. For the orientation of the axes, Eurocode 3 Part 1-1 (2006) convention was used. Because the sections of the elements are very slender, torsional stiffness is very low, so this parameter was considered negligible. The shear areas $\left(A_{s y}\right.$ and $\left.A_{s z}\right)$ were allocated to the straight segments of the section, so curved corners were neglected (Fig. 3).

To model the side sheets of the walls (sw and few) quadrangle plain finite elements were used (thick shell), with the thickness $(e)$ of the respective plate. However, as the sheets are trapezoidal, it presents a higher rigidity in the vertical direction (orthotropic sheet), so bar elements were added to simulate the increase of rigidity in such direction. The spacing of such elements (Fig. 4) is $30 \mathrm{~cm}$ (average spacing between the ribs of the sheet). The sections of these bars were calculated so that the stiffness of the 
ensemble (flat sheet + bar) in the vertical direction is equal to the rigidity of the trapezoidal sheet (Table 5).

The cover plate was modeled using plane finite elements because it has no ribs near the supports (see Tables 2 and 3). An equivalent thickness was calculated to ensure the same sectional area per unit length $(2.17 \mathrm{~mm})$.
Figure 5 illustrates the numerical models implemented with software LUSAS. For the support conditions, it was assumed that all the translations in the four lower corners were restrained, because containers are designed to be supported by the corner pieces. A Young's modulus of $210 \mathrm{GPa}$ and a Poisson's ratio of 0.30 were assumed.

Table 2. Elements of the shipping container 20 'HC

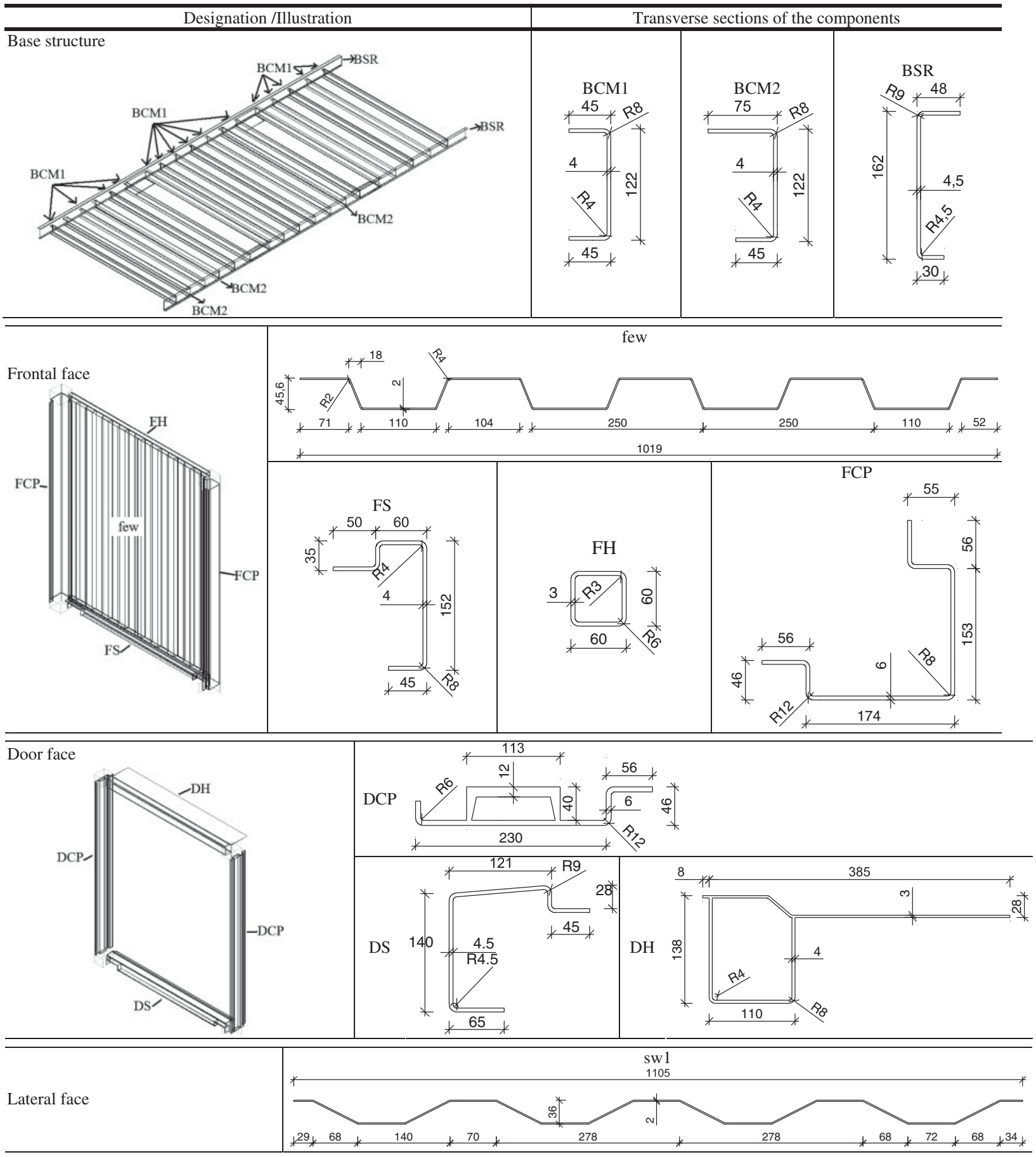


Table 2 (Continued)

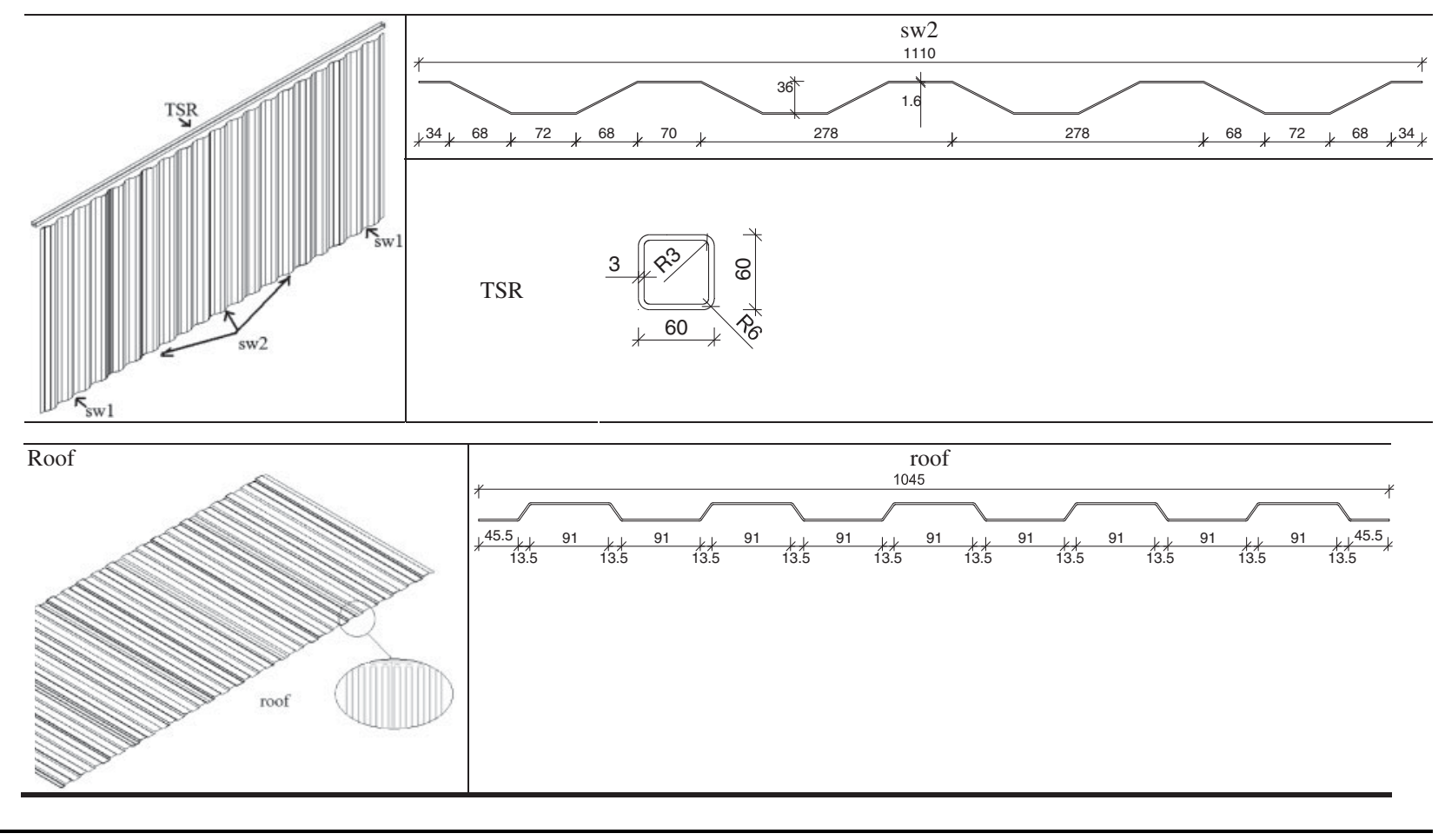

Eight loading cases (Table 6), concentrated and linear, were considered. These cases aim to simulate possible situations of loading transmission between containers and between these and other structural elements. The cases with concentrated loads (load cases 1, 3, 5, and 7 illustrated in Table 6) intended to simulate situations where the containers are connected together only by the corner pieces. The cases with linear loads (load cases 2, 4, 6, and 8 illustrated in Table 6) intended to simulate situations where the containers are continuously connected to each other (horizontal loading) or simulate vertical reactions of slab panels (vertical loads). The values considered for the loads (Table 6) are reference values. The situation of distributed loading on the base structure was not simulated since it is already expected that the floor grid elements behaves essentially as beams.

After the numerical calculations, bending moments, axial and shear forces were obtained for the finite elements. As an example, Figure 6 presents the results for one load case.

The prevalent internal forces calculated for each component of the shipping containers are presented in Table 7. The nomenclature used for the forces is in accordance with Eurocode 3 Part 1-3 (2004): axial forces $\left(\mathrm{N}, \mathrm{N}^{+}\right.$or $\left.\mathrm{N}^{-}\right)$, shear forces $(\mathrm{Vz}$ and $\mathrm{Vy})$ and bending moments (Mz and My). It was observed that, for the majority of the components, the most prominent internal force is the axial force, eventually combined with moderate bending moments and shear forces.

The global results show that containers have a rigid behavior. Such behavior can be explained by the continuous connection between many of the elements of the container.

\section{Code's provisions for safety verification}

To verify the safety of the structural elements of the containers, the structural engineer must follow structural codes that rule the design of structures. In this particular case, for steel structures and for the European space, Eurocode 3 should be used.

\subsection{Classification of sections}

For steel elements, Eurocode 3 Part 1-1 (2006) classifies the sections in order to take into account local buckling effect on the strength and capacity rotation of the section (Class 1-4). According to Clause 5.5 of Eurocode 3 Part 1-1 (2006), this classification is based on the ratio between the length and the thickness $(c / t)$ of the fully or partially compressed elements that compose sections (webs and flanges), the internal forces of the section (axial force or bending moment) and the structural steel class. The limit values of the $c / t$ ratios are given in Table 5.2 of Eurocode 3 Part 1-1 (2006).

Based on the results of the Section 3 (the majority of the components of the containers were 
subjected essentially to axial forces), the classification of the sections was made considering that all the elements that compose the section are in compression (situation less favorable for local buckling). It was observed also that, except for elements BCM1, BCM3, BCM4, BSR, FS, FCP, DCP, and TSR for model $40^{\prime} \mathrm{HC}$ and for elements BCM1, BCR, FS, FH, FCP, and DCP for model 20'HC, the remaining sections of cold-formed profiles are classified as Class 4. Clause 5.5.2 (2) of Eurocode 3 Part 1-1 (2006) states that for these elements, the reduction in strength due to local buckling effect should be considered by the calculation of effective widths for elements that compose the section, according to Eurocode 3 Part 1-5 (2003) for noncommercial sections (Johansson et al. 2001). For commercial cold-formed sections, Eurocode 3 Part 1-3 (2004) should be used (Davies 2000; Rondal 2000).

\subsection{Calculation of the effective sections}

The calculation of the effective sections depends on the stress distribution, which depends on the internal forces. Based on the simplification adopted in Section 4.1 (all the elements of the sections are in compression), the calculation of the effective sections assumes that the section is composed by individual plates. The effective geometrical properties are calculated by the usual methods, ignoring noneffective areas. After this, the safety verification of Class 4 sections subjected to normal stresses is made in the same way as for Class 3 sections (Eurocode 3 Part 1-1 2006).

According to Clause 4.4 of Eurocode 3 Part 1-5 (2003), the effective area of a plate in compression, $A_{c, \text { eff }}$, with area $A_{c}$, is given by:

$$
A_{c, e f f}=\rho_{c} \cdot A_{\mathrm{c}}
$$

where $\rho_{c}$ is a reduction factor for the plate buckling.

For internal elements (webs), $\rho_{c}$ is given by:

$$
\rho_{c}=1 \text { for } \bar{\lambda}_{p} \leq 0.673
$$

Table 3. Elements of the shipping container 40' $\mathrm{HC}$

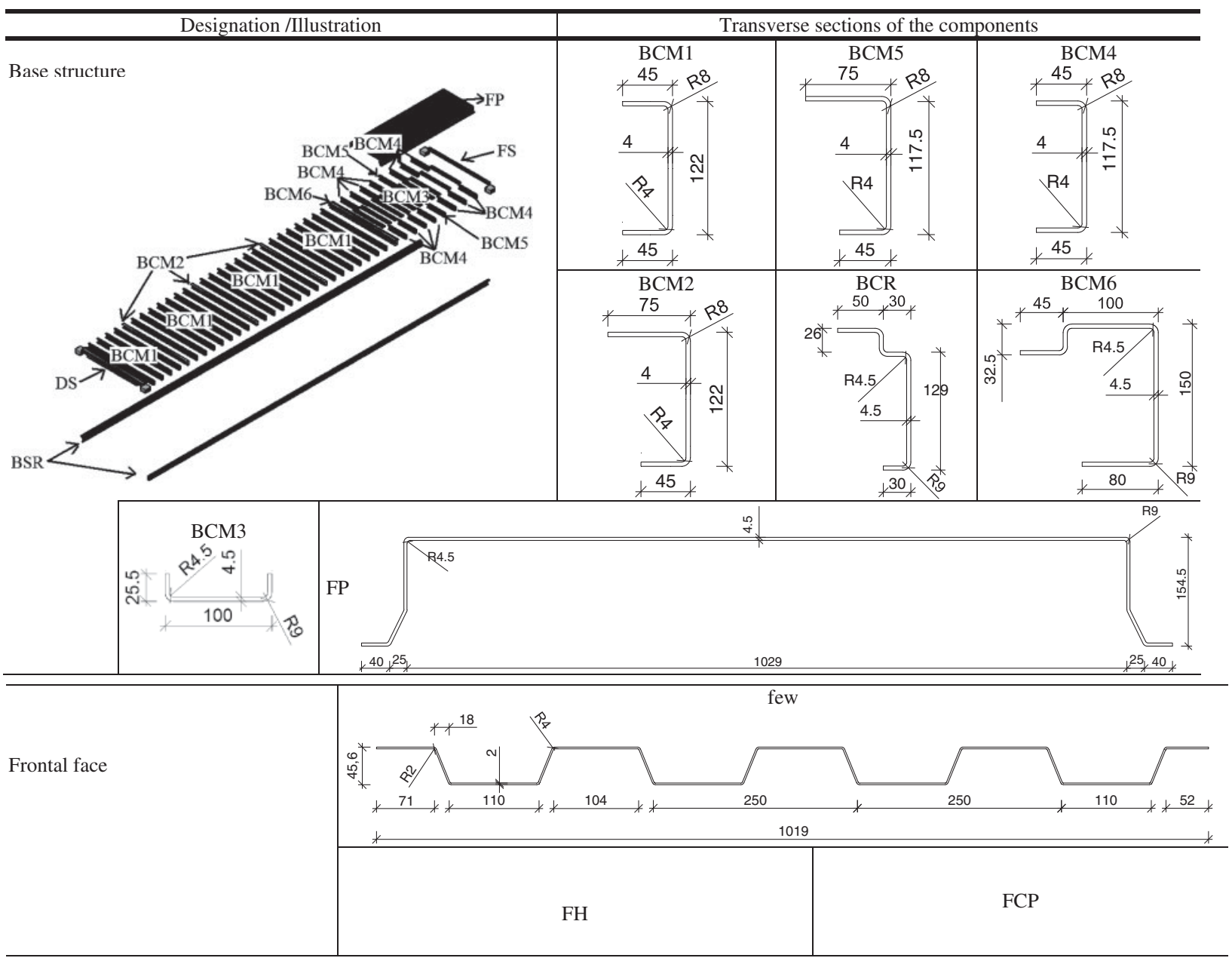


Table 3 (Continued)
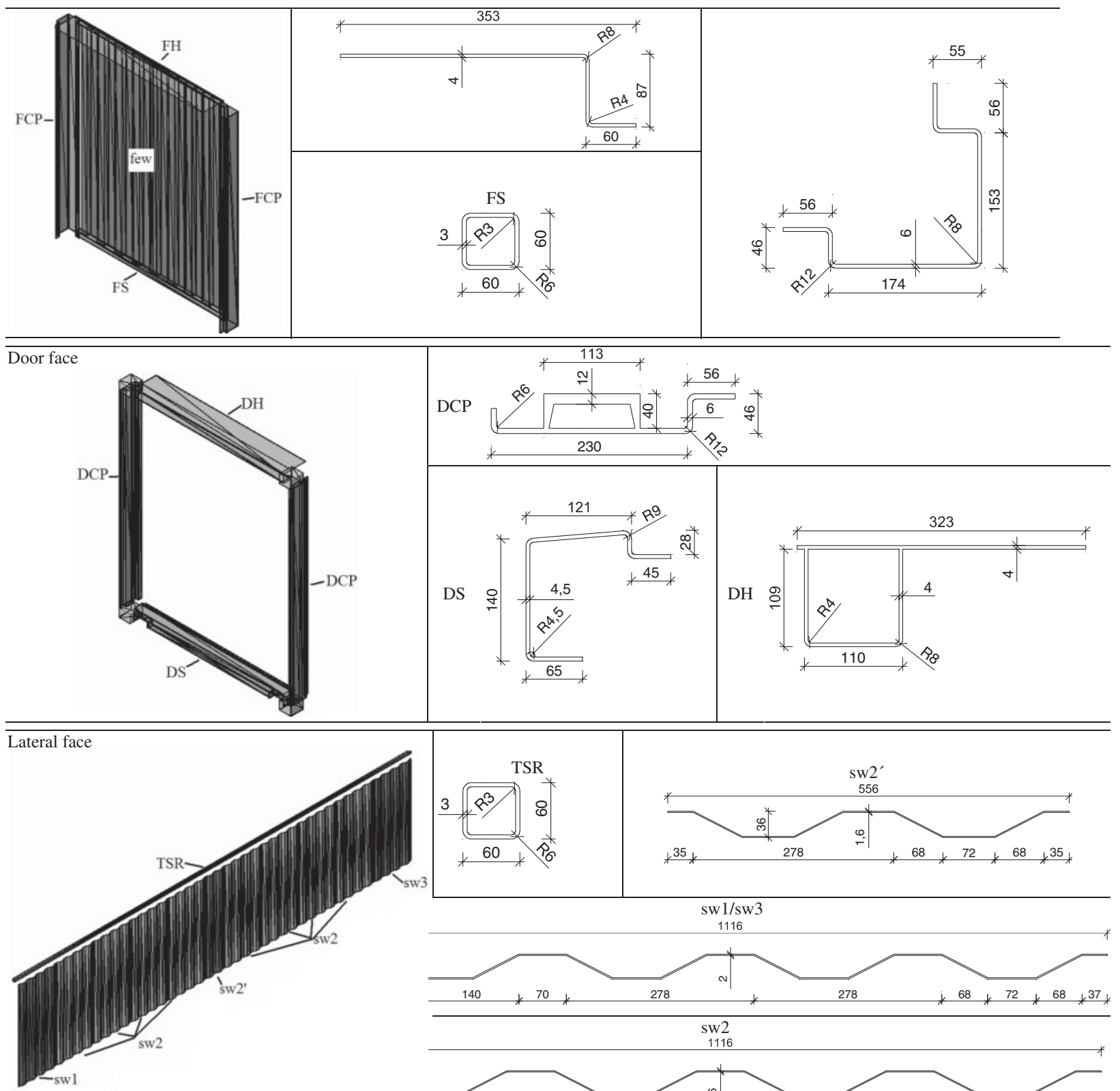

* $37 \times 68 \times 72 \times 68 \times 70 \times \quad 278$

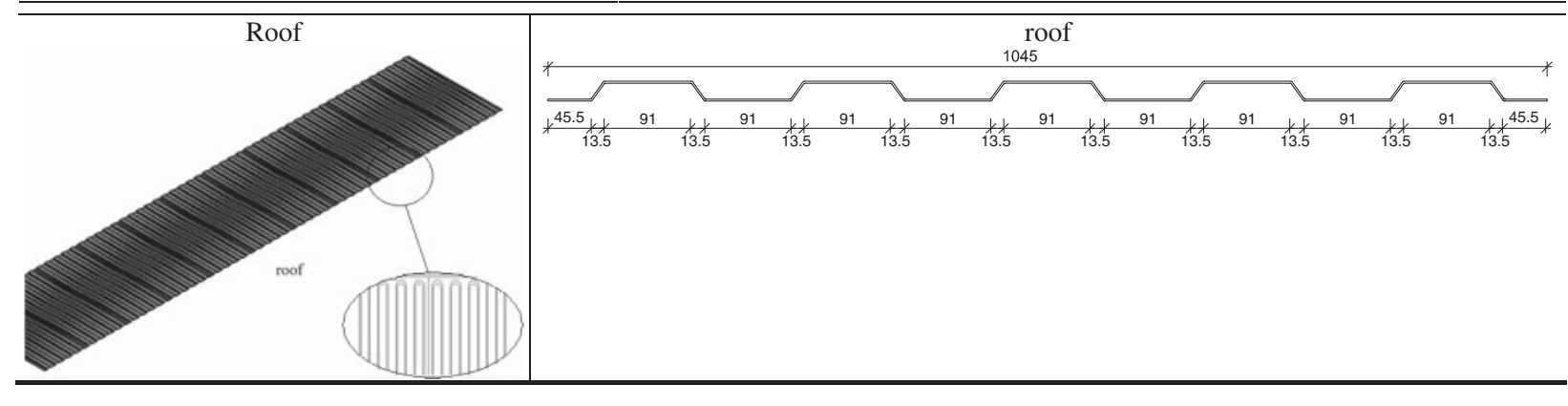


Table 4. Geometrical properties of the gross sections

\begin{tabular}{|c|c|c|c|c|c|}
\hline Profile & $A\left(\mathrm{~m}^{2}\right)$ & $I_{y}\left(\mathrm{~m}^{4}\right)$ & $I_{z}\left(\mathrm{~m}^{4}\right)$ & $A_{s y}\left(\mathrm{~m}^{2}\right)$ & $A_{s z}\left(\mathrm{~m}^{2}\right)$ \\
\hline BCM1 & $7.95 \mathrm{E}-04$ & $1.67 \mathrm{E}-06$ & $1.44 \mathrm{E}-07$ & $2.96 \mathrm{E}-04$ & $4.24 \mathrm{E}-04$ \\
\hline BCM2 & $9.15 \mathrm{E}-04$ & $2.04 \mathrm{E}-06$ & $4.00 \mathrm{E}-07$ & $4.16 \mathrm{E}-04$ & $4.24 \mathrm{E}-04$ \\
\hline $\mathrm{BCM}^{40} \mathrm{HC}$ & $0.61 \mathrm{E}-03$ & $0.29 \mathrm{E}-05$ & $0.74 \mathrm{E}-06$ & $3.69 \mathrm{E}-04$ & $1.49 \mathrm{E}-04$ \\
\hline $\mathrm{BCM} 4^{40}{ }^{\prime} \mathrm{HC}$ & $7.89 \mathrm{E}-04$ & $1.57 \mathrm{E}-06$ & $1.43 \mathrm{E}-07$ & $2.96 \mathrm{E}-04$ & $4.06 \mathrm{E}-04$ \\
\hline BCM $5^{40} \mathrm{HC}$ & $9.09 \mathrm{E}-04$ & $1.90 \mathrm{E}-06$ & $3.98 \mathrm{E}-07$ & $4.16 \mathrm{E}-04$ & $4.06 \mathrm{E}-04$ \\
\hline $\mathrm{BSR}^{40} \mathrm{HC}$ & $1.13 \mathrm{E}-03$ & $3.27 \mathrm{E}-06$ & $5.29 \mathrm{E}-07$ & $3.53 \mathrm{E}-04$ & $5.56 \mathrm{E}-04$ \\
\hline $\mathrm{BSR}^{20} \mathrm{HC}$ & $1.01 \mathrm{E}-03$ & $3.31 \mathrm{E}-06$ & $1.36 \mathrm{E}-07$ & $1.94 \mathrm{E}-07$ & $2.70 \mathrm{E}-04$ \\
\hline BCM $6^{40} \mathrm{HC}$ & $1.75 \mathrm{E}-03$ & $5.77 \mathrm{E}-06$ & $3.28 \mathrm{E}-06$ & $8.71 \mathrm{E}-04$ & $6.59 \mathrm{E}-04$ \\
\hline $\mathrm{BFP}^{40} \mathrm{HC}$ & $8.73 \mathrm{E}-04$ & $2.08 \mathrm{E}-06$ & $2.72 \mathrm{E}-07$ & $2.23 \mathrm{E}-04$ & $6.07 \mathrm{E}-04$ \\
\hline $\mathrm{DCP}$ & $3.81 \mathrm{E}-03$ & $1.12 \mathrm{E}-06$ & $1.80 \mathrm{E}-05$ & $2.57 \mathrm{E}-03$ & $7.02 \mathrm{E}-04$ \\
\hline $\mathrm{DH}^{40} \mathrm{HC}$ & $2.55 \mathrm{E}-03$ & $4.97 \mathrm{E}-06$ & $2.02 \mathrm{E}-05$ & $1.67 \mathrm{E}-03$ & $8.08 \mathrm{E}-04$ \\
\hline $\mathrm{DH}^{20} \mathrm{HC}$ & $2.57 \mathrm{E}-03$ & $5.84 \mathrm{E}-06$ & $3.02 \mathrm{E}-05$ & $4.81 \mathrm{E}-06$ & $1.53 \mathrm{E}-03$ \\
\hline DS & $1.70 \mathrm{E}-03$ & $5.06 \mathrm{E}-06$ & $4.47 \mathrm{E}-06$ & $8.96 \mathrm{E}-04$ & $6.52 \mathrm{E}-04$ \\
\hline FCP & $2.98 \mathrm{E}-03$ & $1.28 \mathrm{E}-05$ & $1.45 \mathrm{E}-05$ & $1.35 \mathrm{E}-03$ & $1.21 \mathrm{E}-03$ \\
\hline $\mathrm{FH}^{40 ' \mathrm{HC}}$ & $1.74 \mathrm{E}-03$ & $1.73 \mathrm{E}-06$ & $1.84 \mathrm{E}-05$ & $1.36 \mathrm{E}-03$ & $2.84 \mathrm{E}-04$ \\
\hline $\mathrm{FH}^{20} \mathrm{HC}$ & $6.61 \mathrm{E}-04$ & $3.51 \mathrm{E}-07$ & $3.51 \mathrm{E}-07$ & $0.00 \mathrm{E}+00$ & $2.88 \mathrm{E}-04$ \\
\hline $\mathrm{FS}^{40} \mathrm{HC}$ & $6.80 \mathrm{E}-04$ & $3.66 \mathrm{E}-07$ & $3.66 \mathrm{E}-07$ & $2.88 \mathrm{E}-04$ & $2.88 \mathrm{E}-04$ \\
\hline $\mathrm{FS}^{20} \mathrm{HC}$ & $1.26 \mathrm{E}-03$ & $3.59 \mathrm{E}-06$ & $1.16 \mathrm{E}-06$ & $-7.42 \mathrm{E}-07$ & $4.91 \mathrm{E}-04$ \\
\hline TSR & $6.80 \mathrm{E}-04$ & $3.66 \mathrm{E}-07$ & $3.66 \mathrm{E}-07$ & $2.88 \mathrm{E}-04$ & $2.88 \mathrm{E}-04$ \\
\hline Sheet & $A\left(\mathrm{~m}^{2}\right)$ & $I_{y}\left(\mathrm{~m}^{4}\right)$ & $I_{z}\left(\mathrm{~m}^{4}\right)$ & $e(\mathrm{~m})$ & $l(\mathrm{~m})$ \\
\hline $\mathrm{sw} 1 / \mathrm{sw} 3^{40^{\prime} \mathrm{HC}}$ & $2.36 \mathrm{E}-03$ & $4.49 \mathrm{E}-07$ & $2.45 \mathrm{E}-04$ & $2.00 \mathrm{E}-03$ & 1.116 \\
\hline $\mathrm{SW} 1^{20 \prime \mathrm{HC}}$ & $2.36 \mathrm{E}-03$ & $4.49 \mathrm{E}-07$ & $2.45 \mathrm{E}-04$ & $2.00 \mathrm{E}-03$ & 1.105 \\
\hline $\mathrm{sw} 2^{40^{\prime} \mathrm{HC}}$ & $1.89 \mathrm{E}-03$ & $3.67 \mathrm{E}-07$ & $1.96 \mathrm{E}-04$ & $1.60 \mathrm{E}-03$ & 1.116 \\
\hline $\mathrm{sw} 2^{20^{\prime} \mathrm{HC}}$ & $1.89 \mathrm{E}-03$ & $3.67 \mathrm{E}-07$ & $1.96 \mathrm{E}-04$ & $1.60 \mathrm{E}-03$ & 1.019 \\
\hline few & $2.49 \mathrm{E}-03$ & $9.44 \mathrm{E}-07$ & $2.13 \mathrm{E}-04$ & $2.00 \mathrm{E}-03$ & 1.019 \\
\hline
\end{tabular}

$$
\begin{aligned}
\rho_{c}= & \frac{\bar{\lambda}_{p}-0.055(3+\psi)}{\lambda_{p}^{2}} \leq 1 \text { for } \bar{\lambda}_{p}>0.673, \\
& (3+\psi) \geq 0 .
\end{aligned}
$$

For external elements (flanges), $\rho_{c}$ is given by:

$$
\begin{gathered}
\rho_{c}=1 \text { for } \bar{\lambda}_{p} \leq 0.748 \\
\rho_{c}=\frac{\bar{\lambda}_{p}-0.188(3+\psi)}{\bar{\lambda}_{p}^{2}} \leq 1 \text { for } \bar{\lambda}_{p}>0.748 .
\end{gathered}
$$

The slenderness coefficient for one plate $\bar{\lambda}_{p}$ is given by:

$$
\bar{\lambda}_{p}=\sqrt{\frac{f_{y}}{\sigma_{c r}}}=\frac{\bar{b} / t}{28.4 \cdot \varepsilon \sqrt{k_{\sigma}}},
$$
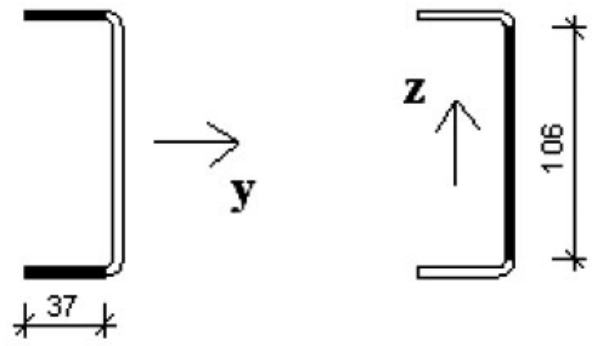

Fig. 3. Definition of shear areas (section BCM1) where $\psi$ - ratio between maximum and minimum stress in the plate (Tables 4.1 and 4.2 of Eurocode 3 Part 1-5 (2003)); $\bar{b}$ - width of the plate, equal to the distance $b_{p}$ between points of adjacent vertices of the element (Fig. 7); $t$ - plate thickness; $k_{\sigma}$ - plate buckling coefficient (Tables 4.3 and 4.4 of Eurocode 3 Part 1-5 (2003)); $\sigma_{c r}$ - critical elastic stress of the plate, calculated by:

$$
\sigma_{c r}=k_{\sigma} \cdot 189,800 \cdot(t / \bar{b})^{2} \text {. }
$$

In accordance with Clause 2.2 (5) of Eurocode 3 Part 1-5 (2003), for a global analysis as the one

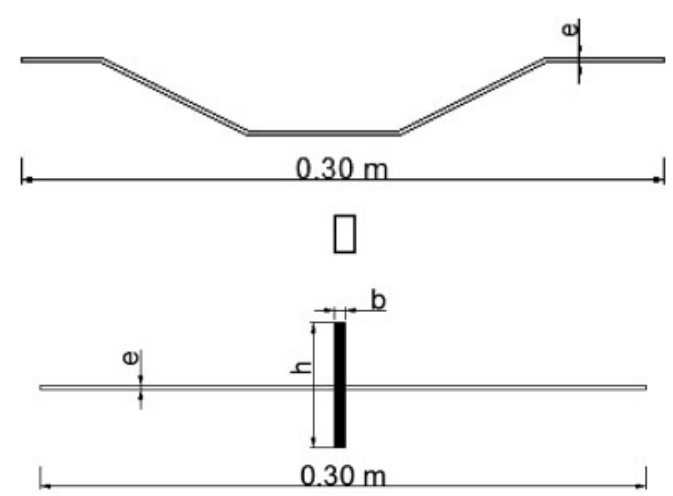

Fig. 4. Modeling of the trapezoidal plate 
Table 5. Geometrical properties of strengthening bars

\begin{tabular}{lcccrr}
\hline Sheet & $b(\mathrm{~m})$ & $h(\mathrm{~m})$ & $A\left(\mathrm{~m}^{2}\right)$ & $I_{y}\left(\mathrm{~m}^{4}\right)$ & $A_{s z}\left(\mathrm{~m}^{2}\right)$ \\
\hline sw1/sw3 ${ }^{40^{\prime} \mathrm{HC}}$ & $1.69 \mathrm{E}-04$ & $2.05 \mathrm{E}-01$ & $3.46 \mathrm{E}-05$ & $1.21 \mathrm{E}-07$ & $2.88 \mathrm{E}-05$ \\
sw2 $2^{40^{\prime} \mathrm{HC}}$ & $1.38 \mathrm{E}-04$ & $2.05 \mathrm{E}-01$ & $2.83 \mathrm{E}-05$ & $9.90 \mathrm{E}-08$ & $2.36 \mathrm{E}-05$ \\
few $^{40^{\prime} \mathrm{HC}}$ & $3.47 \mathrm{E}-04$ & $2.07 \mathrm{E}-01$ & $7.17 \mathrm{E}-05$ & $2.56 \mathrm{E}-07$ & $5.98 \mathrm{E}-05$ \\
sw $^{20} \mathrm{HC}$ & $1.72 \mathrm{E}-04$ & $2.03 \mathrm{E}-01$ & $3.49 \mathrm{E}-05$ & $1.20 \mathrm{E}-07$ & $2.91 \mathrm{E}-05$ \\
sw2 $^{20} \mathrm{HC}$ & $1.39 \mathrm{E}-04$ & $2.04 \mathrm{E}-01$ & $2.84 \mathrm{E}-05$ & $9.84 \mathrm{E}-08$ & $2.37 \mathrm{E}-05$ \\
Few $^{20} \mathrm{HC}$ & $8.39 \mathrm{E}-04$ & $1.58 \mathrm{E}-01$ & $1.33 \mathrm{E}-04$ & $2.78 \mathrm{E}-07$ & $1.11 \mathrm{E}-04$ \\
\hline
\end{tabular}

carried out in Section 3, the reduction of the sections can be neglected when the effective area of an element in compression is greater than $50 \%$ of the gross area $\left(\rho_{c} \geq 0.5\right)$. Thus, it is necessary to check this condition to know if the elastic analysis of the containers performed in Section 3 (with gross area) is valid or not. For this purpose, effective sections were computed for all Class 4 elements (considering the section in compression). Table 9 illustrates all the calculated effective sections, so that a comparative analysis can be carried out with Tables 2 and 3. It is observed that for all elements, excepted FP element, the reduction of the area is lesser than $50 \%$ of the gross area. Therefore, it can be considered that the global results of Section 3 remain valid. New geometrical properties for the effective sections were computed to be used to check for safety design (Table 8).

\section{Case study}

This section presents a real case study based on a single-family house for which a structural solution based on refurbished shipping containers (20'HC and 40 'HC) was studied.

\subsection{Architecture}

Figures $8-11$ present some architectural drawings of the building.

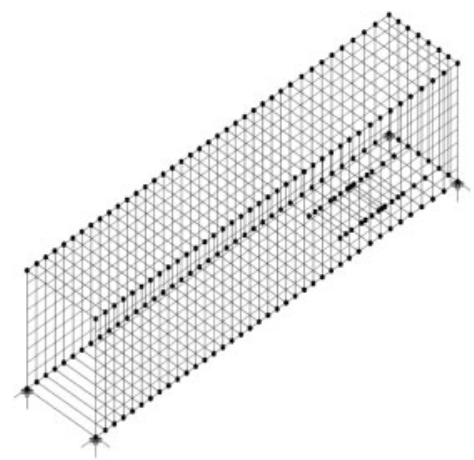

40 'HC

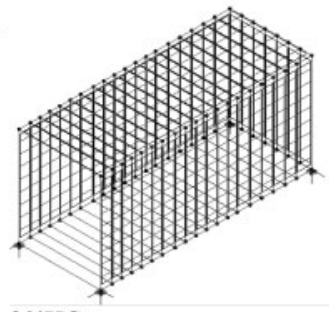

20 'HC

Fig. 5. Numerical model of the shipping containers
Table 6. Load cases analyzed

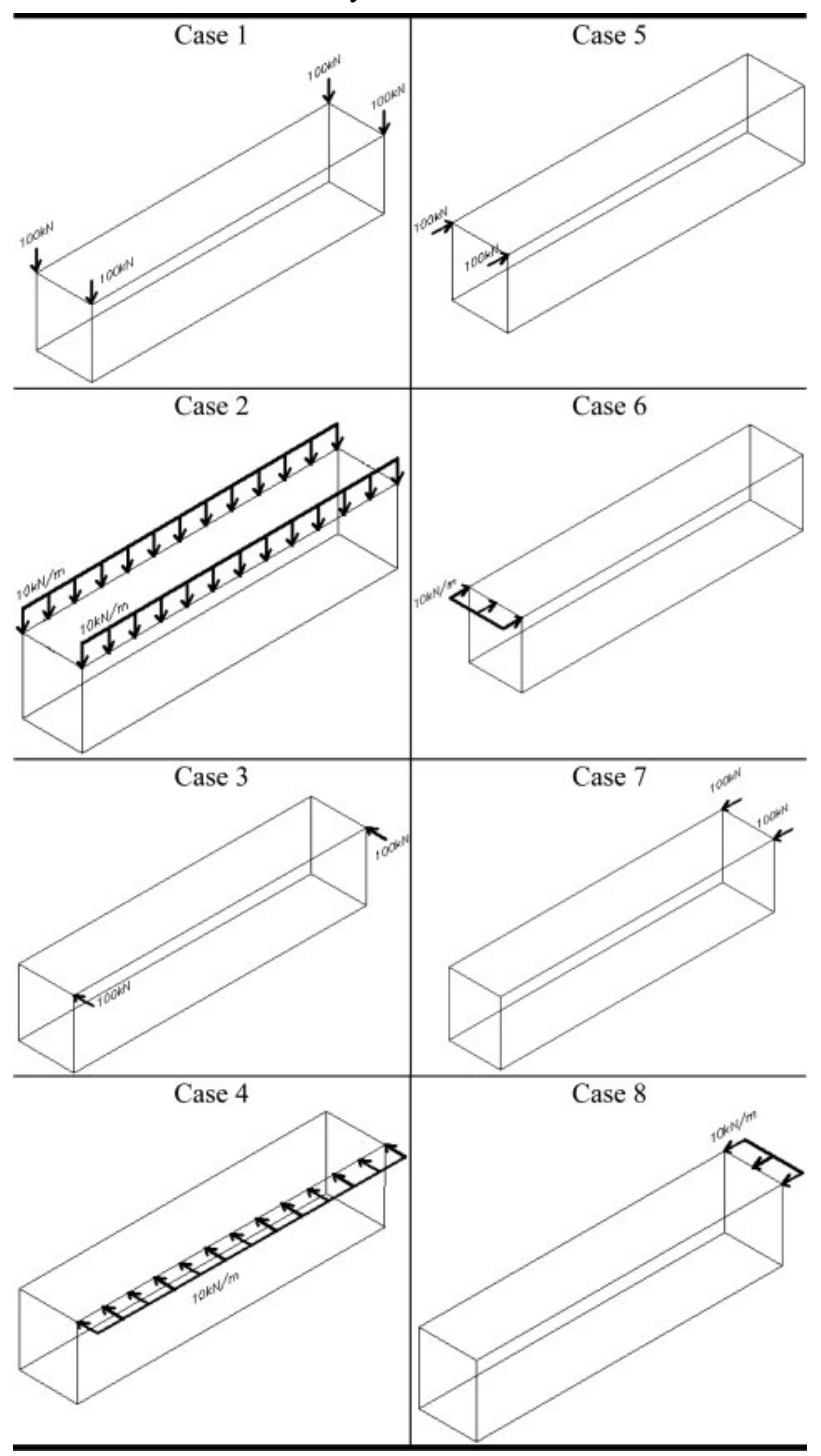

The building with two floors has an area of $115 \mathrm{~m}^{2}$ at Floor 0 and $82 \mathrm{~m}^{2}$ at Floor 1. This last one is partially suspended. The ceiling height is $2.54 \mathrm{~m}$ on both floors.

\subsection{Structural conception}

After the study of some configurations, the chosen solution is composed with 10 shipping containers, 
Table 7. Preponderant internal forces

\begin{tabular}{|c|c|c|c|}
\hline Element & Internal forces & Element & Internal forces \\
\hline DS & $N ; V y ; V z ; M y ; M z$ & BCM1 & $N^{+} ; V z ; M y$ \\
\hline $\mathrm{DCP}$ & $N ; V y ; V z ; M y ; M z$ & BCM2 & $N^{+} ; V z ; M y$ \\
\hline $\mathrm{DH}^{40 \prime \mathrm{HC}}$ & $N^{+}$ & BCM3 & $N ; V z ; M y$ \\
\hline $\mathrm{DH}^{20} \mathrm{HC}$ & $N ; V y ; V z ; M y ; M z$ & BCM4 & $N ; V z ; M y$ \\
\hline $\mathrm{FH}^{40} \mathrm{HC}$ & $N ; V z ; M y$ & BCM5 & $N ; V z ; M y$ \\
\hline $\mathrm{FH}^{20} \mathrm{HC}$ & $N$ & BCM6 & $N ; F z ; M y$ \\
\hline $\mathrm{FS}^{40} \mathrm{HC}$ & $N^{+}$ & FP & $N^{-} ; V z ; M y$ \\
\hline $\mathrm{TSR}^{20 \prime \mathrm{HC}}$ & $N ; V z ; M y$ & Few & $N ; V z ; M y$ \\
\hline $\mathrm{TSR}^{40 \prime \mathrm{HC}}$ & $N ; V z ; M y$ & $\mathrm{sw}_{1 / 3}^{40} \mathrm{HC}$ & $N$ \\
\hline $\mathrm{FS}^{20 \prime H C}$ & $N ; V z ; M y$ & $\mathrm{sw}_{1 / 3}^{20} \mathrm{HC}$ & $N$ \\
\hline FCP & $N ; V y ; V z ; M y ; M z$ & $\mathrm{sw}_{2}^{40} \mathrm{HC}$ & $N$ \\
\hline $\mathrm{BSR}^{40} \mathrm{HC}$ & $N ; V z ; M y$ & $\mathrm{sw}_{2}^{20} \mathrm{HC}$ & $N$ \\
\hline $\mathrm{BSR}^{20 \prime \mathrm{HC}}$ & $N ; V z ; M y$ & & \\
\hline
\end{tabular}

5 models $20^{\prime} \mathrm{HC}$ and 5 models 40 ' $\mathrm{HC}$ (Figs 12 and 13). It should be pointed that the architecture had to be optimized to allow the full utilization of the containers areas.

In a preliminary study phase it was verified that the suspension of the containers in the Floor 1 was not compatible with their resistance because of the openings in the walls. This problem was solved by using

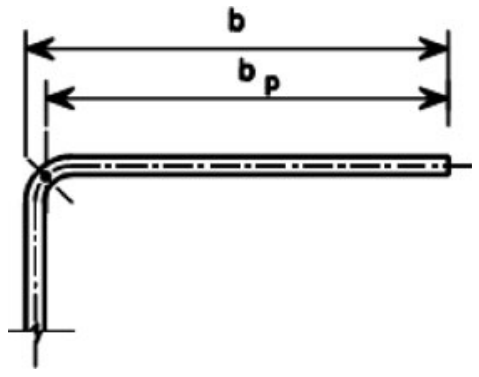

Fig. 7. Width of the plate

two external and lateral trusses along the entire length of the containers, continuously connected to the containers by welding. These trusses are supported by steel columns with soil foundations (Fig. 13). The geometry of the lateral trusses was defined taking into account esthetic aspects as well as the constraints of architectural design, namely the location and the dimensions of the openings. RHSH profiles (Class S355) were used to compose external trusses and steel columns.

Structural coverage for flat floors is executed by using adapted base structures of additional 20'HC containers. For Floor 1, the base structures were

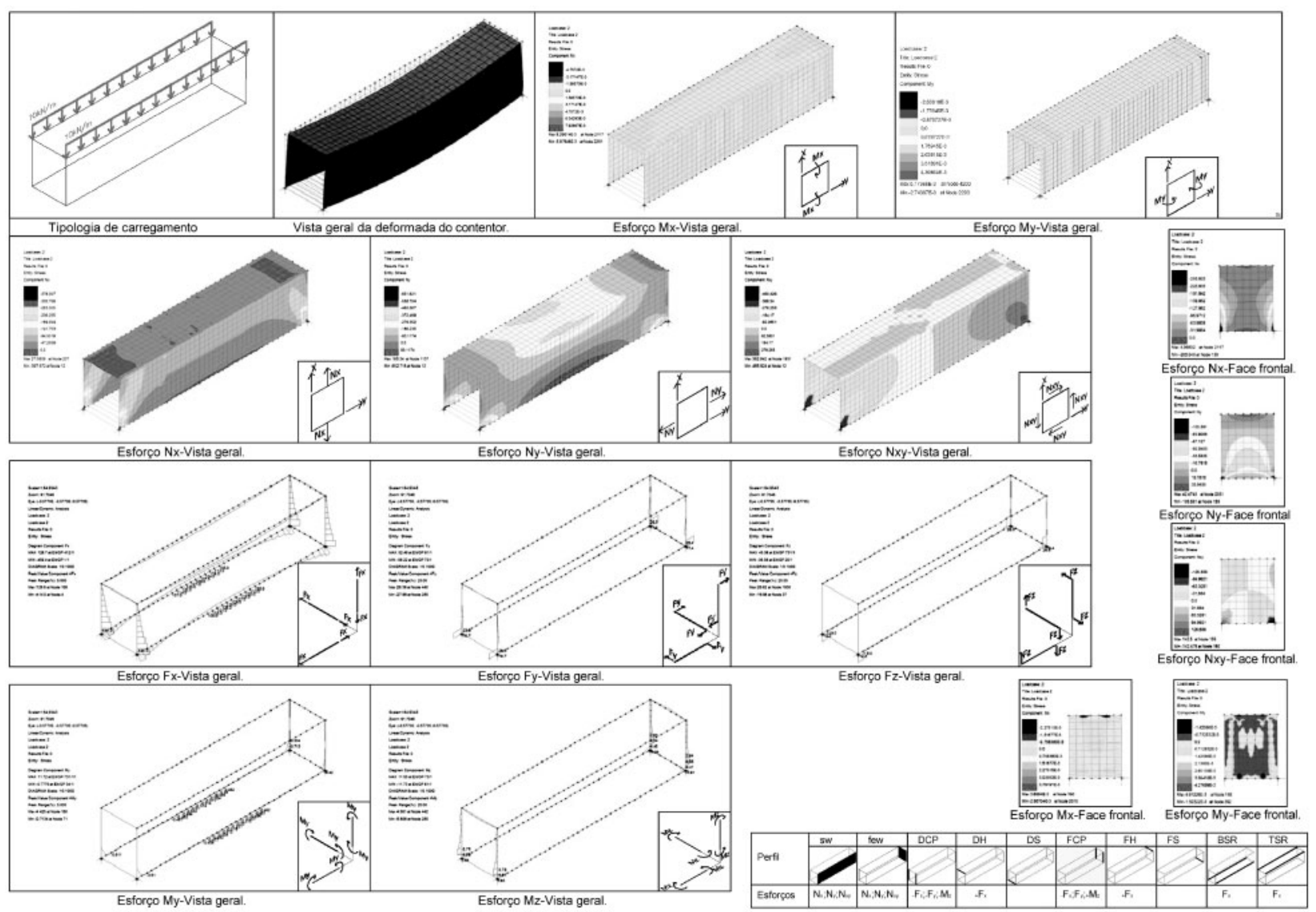

Fig. 6. Results obtained for load case 2 (model 40'HC) 
Table 8. Geometrical properties (effective sections)

\begin{tabular}{|c|c|c|c|c|c|c|c|}
\hline Profiles & $A\left(\mathrm{~mm}^{2}\right)$ & $I_{y}\left(\mathrm{~mm}^{4}\right)$ & $I_{z}\left(\mathrm{~mm}^{4}\right)$ & $A_{s y}\left(\mathrm{~mm}^{2}\right)$ & $A_{s z}\left(\mathrm{~mm}^{2}\right)$ & $W_{\text {el. } y}\left(\mathrm{~mm}^{3}\right)$ & $W_{e l . z}\left(\mathrm{~mm}^{3}\right)$ \\
\hline $\mathrm{DS}$ & $1.68 \mathrm{E}-3$ & $4.83 \mathrm{E}-6$ & $4.46 \mathrm{E}-6$ & $8.70 \mathrm{E}-4$ & $6.52 \mathrm{E}-4$ & $5.22 \mathrm{E}-5$ & $3.82 \mathrm{E}-5$ \\
\hline $\mathrm{DH}^{40 \prime \mathrm{HC}}$ & $1.96 \mathrm{E}-3$ & $3.99 \mathrm{E}-6$ & $4.85 \mathrm{E}-6$ & $1.08 \mathrm{E}-3$ & $8.08 \mathrm{E}-4$ & $6.19 \mathrm{E}-5$ & $4.66 \mathrm{E}-5$ \\
\hline $\mathrm{DH}^{20 \prime \mathrm{HC}}$ & $1.89 \mathrm{E}-3$ & $4.85 \mathrm{E}-6$ & $4.31 \mathrm{E}-6$ & $8.37 \mathrm{E}-4$ & $9.16 \mathrm{E}-4$ & $6.85 \mathrm{E}-5$ & $4.43 \mathrm{E}-5$ \\
\hline $\mathrm{FH}^{40} \mathrm{HC}$ & $7.58 \mathrm{E}-4$ & $9.20 \mathrm{E}-7$ & $4.69 \mathrm{E}-7$ & $3.99 \mathrm{E}-4$ & $2.84 \mathrm{E}-4$ & $2.01 \mathrm{E}-5$ & $8.09 \mathrm{E}-6$ \\
\hline BCM2 & $8.38 \mathrm{E}-4$ & $1.81 \mathrm{E}-6$ & $2.04 \mathrm{E}-7$ & $3.37 \mathrm{E}-4$ & $4.24 \mathrm{E}-4$ & $2.83 \mathrm{E}-5$ & $4.83 \mathrm{E}-6$ \\
\hline BCM5 & $8.19 \mathrm{E}-4$ & $1.65 \mathrm{E}-6$ & $2.01 \mathrm{E}-7$ & $3.37 \mathrm{E}-4$ & $4.06 \mathrm{E}-4$ & $2.69 \mathrm{E}-5$ & $4.80 \mathrm{E}-6$ \\
\hline BCM6 & $1.64 \mathrm{E}-3$ & $5.03 \mathrm{E}-6$ & $3.14 \mathrm{E}-6$ & $7.88 \mathrm{E}-4$ & $6.59 \mathrm{E}-4$ & $5.49 \mathrm{E}-5$ & $3.02 \mathrm{E}-5$ \\
\hline FP & $2.47 \mathrm{E}-1$ & $9.14 \mathrm{E}-6$ & $6.86 \mathrm{E}-5$ & $5.92 \mathrm{E}-4$ & $8.48 \mathrm{E}-4$ & $9.90 \mathrm{E}-5$ & $1.19 \mathrm{E}-3$ \\
\hline Few & $1.92 \mathrm{E}-3$ & $6.74 \mathrm{E}-7$ & $1.53 \mathrm{E}-5$ & - & - & $2.89 \mathrm{E}-5$ & $3.22 \mathrm{E}-4$ \\
\hline $\mathrm{sw}_{1 / 3}^{40} \mathrm{HC}$ & $2.13 \mathrm{E}-3$ & $4.19 \mathrm{E}-7$ & $2.15 \mathrm{E}-5$ & - & - & $2.36 \mathrm{E}-5$ & $3.93 \mathrm{E}-4$ \\
\hline $\mathrm{sw}_{1 / 3}^{20} \mathrm{HC}$ & $2.20 \mathrm{E}-3$ & $4.37 \mathrm{E}-7$ & $2.19 \mathrm{E}-5$ & - & - & $2.34 \mathrm{E}-5$ & $3.95 \mathrm{E}-4$ \\
\hline $\mathrm{Sw}_{2}^{40} \mathrm{HC}$ & $1.40 \mathrm{E}-3$ & $2.85 \mathrm{E}-7$ & $1.43 \mathrm{E}-5$ & - & - & $1.68 \mathrm{E}-5$ & $2.63 \mathrm{E}-4$ \\
\hline $\mathrm{sw}_{2}^{20} \mathrm{HC}$ & $1.47 \mathrm{E}-3$ & $3.06 \mathrm{E}-7$ & $1.46 \mathrm{E}-5$ & - & - & $1.68 \mathrm{E}-5$ & $2.70 \mathrm{E}-4$ \\
\hline
\end{tabular}

Table 9. Effective sections

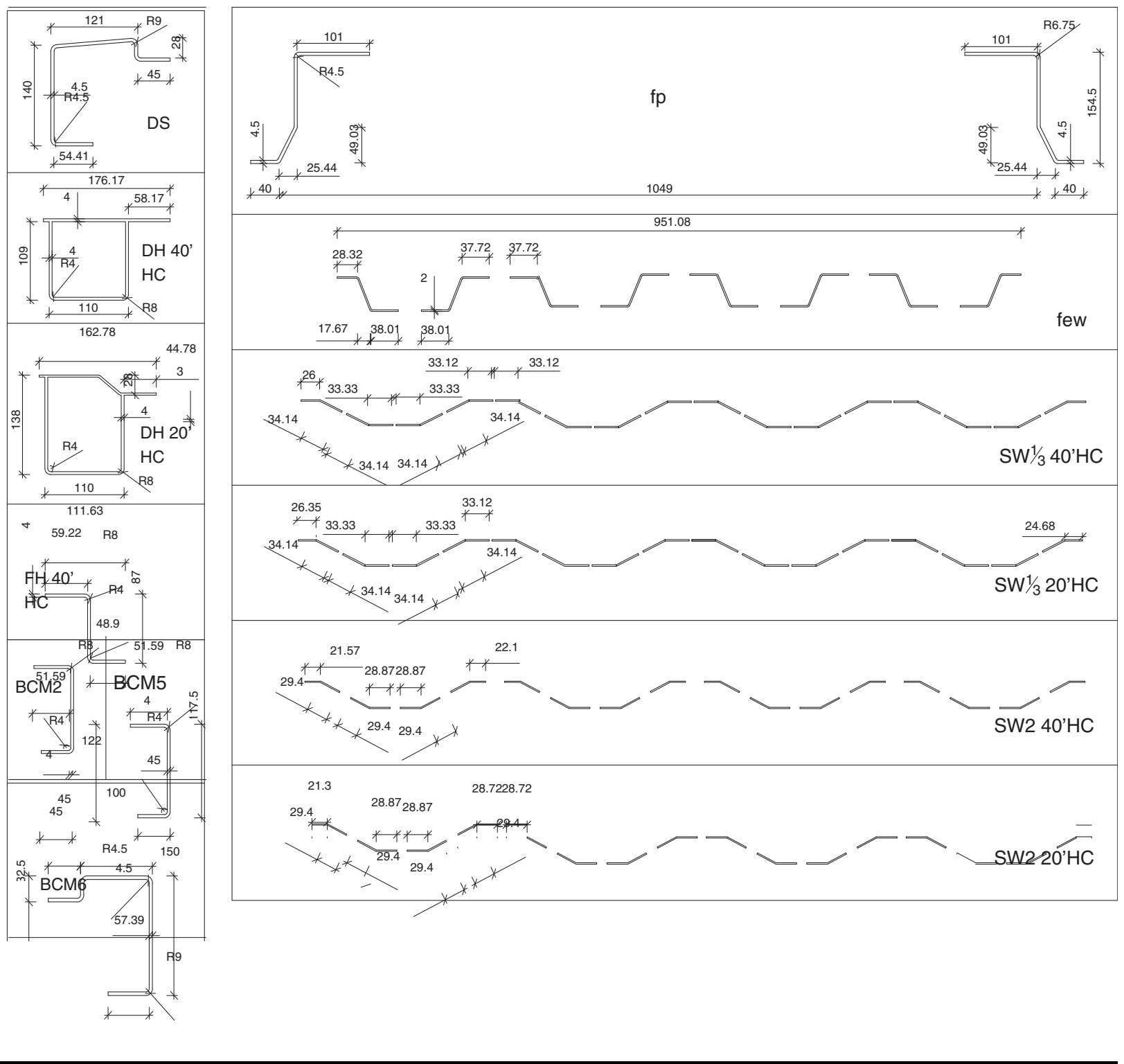



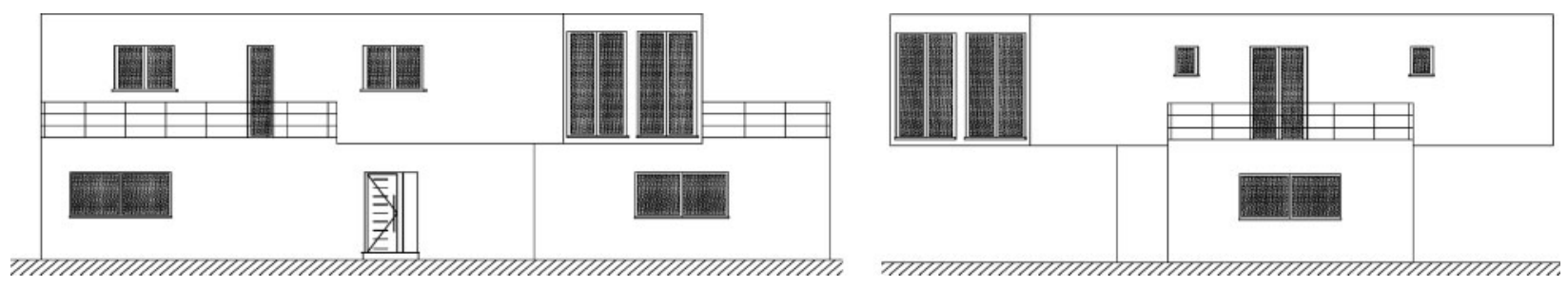

Fig. 8. Single family house: lateral views

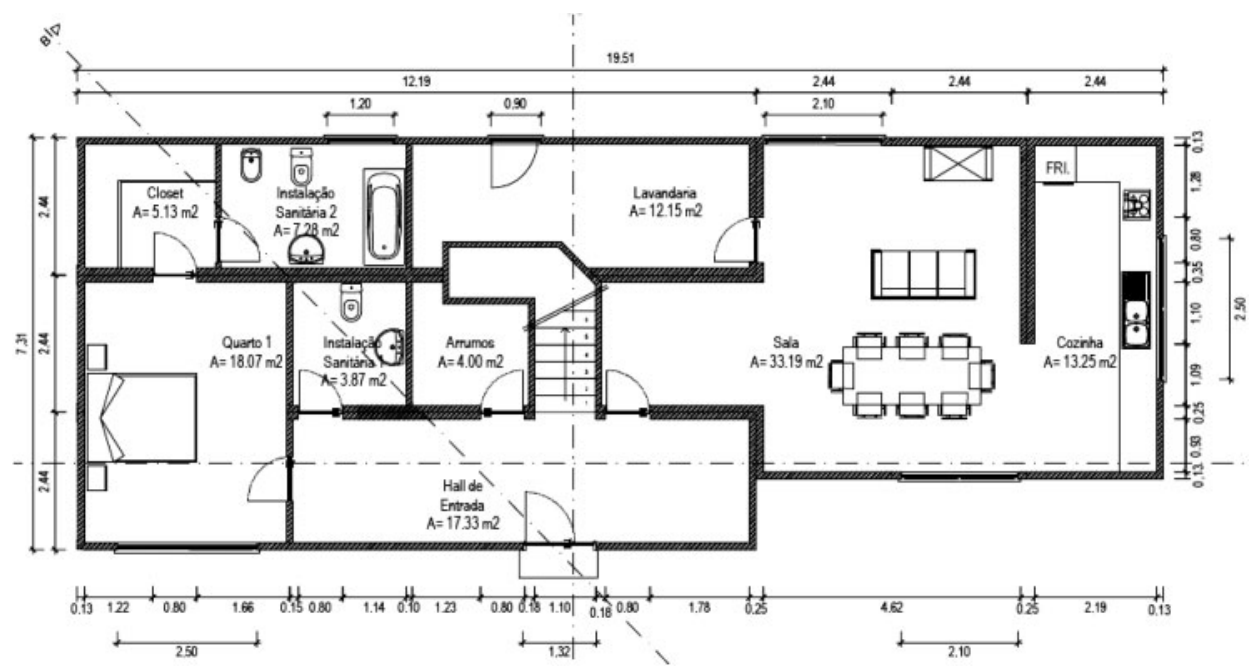

Fig. 9. Single family house: Floor 0

placed on the perpendicular direction and suported on the upper strings of the trusses (Fig. 14).

A reinforced concrete raft foundation was adopted to found containers and strengthening profiles.

\subsection{Refurbishment and preparation of containers}

The remodeling process of shipping containers is initiated by removing the doors as well as replacing original plywood floor. Next, the openings are made by cutting steel wall sheets and profiles in accordance with architectural requirements (some examples are presented in Table 10). With this procedure, containers lose some of its original strength. Therefore, vertical strengthening elements near to the openings (both sides) were added (Figs 15 and 16). TPS profiles were used for the strengthening elements. For one opening, the total area of the strengthening elements is equal to the area of the removed sheet/profile.

The project drawings for the refurbishment and preparation for the steel work warehouses are important in order to ensure no problems on construc- tion place during the assembly of the containers. Such drawings, with full details, should clearly indicate the location and the dimensions of the openings, as well as the location and connection of the strengthening elements. Figures 15 and 16 present preparation drawings for some containers.

\subsection{Assembly of the containers}

Figure 17 illustrates an overview of the containers after assembly (external trusses are not illustrated).

The containers are joined together by welding between some profiles and corner pieces. Figure 18 presents some details of welded connections, namely the section C-C on Floor 1 (Fig. 13) to show the connection between the containers and the external trusses.

\subsection{Numerical model}

To evaluate the internal forces in containers elements, a numerical model (based on the assumptions of Section 3) was implemented with finite elements analysis software (LUSAS) (Fig. 19). Such a model includes the openings, the strengthening profiles, and 


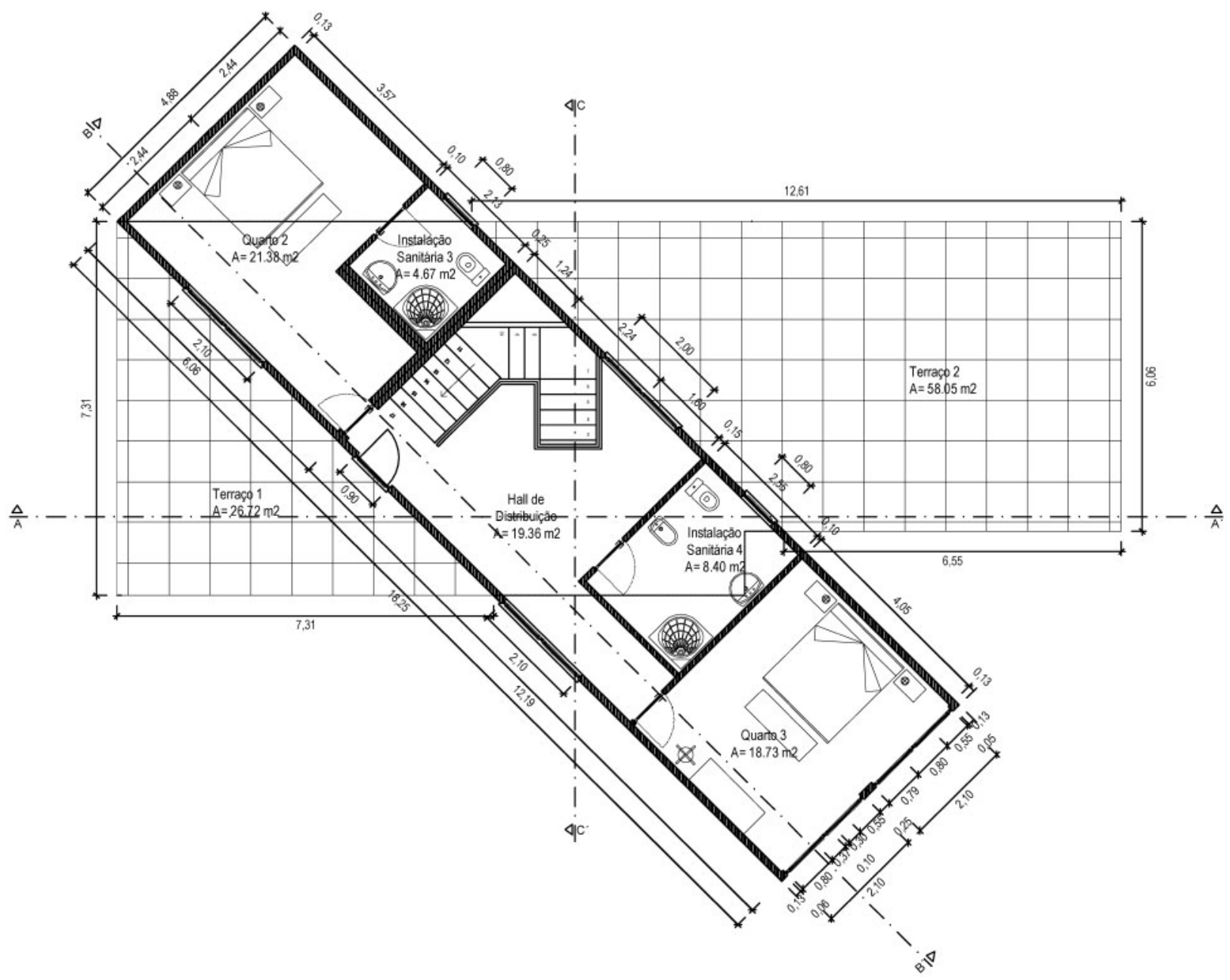

Fig. 10. Single family house: Floor 1

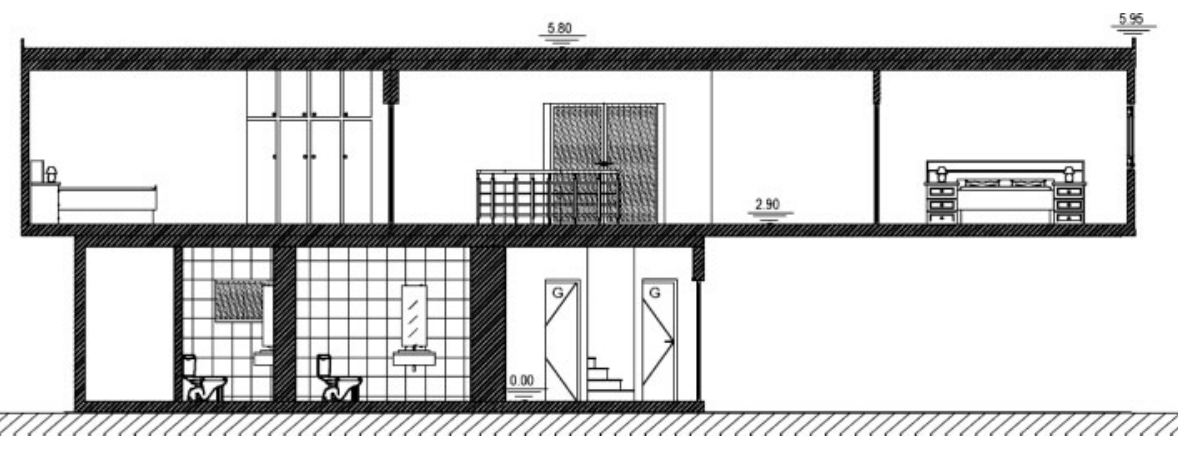

Fig. 11. Single family house: Section B-B

the external trusses. The containers at Floor 0 are simply supported at the lower corner pieces (all translations restrained).

The geometrical properties of container elements were calculated based on gross sections (Tables 4 and 5). For FP profile, the effective section area is less than $50 \%$ of gross section area (Section 4.2), so effective geometrical properties were considered (Table 8). For the strengthening elements (TPS profiles) and external trusses elements (RHSH profiles), the chosen commercial section was based on pre-design simplified models. 


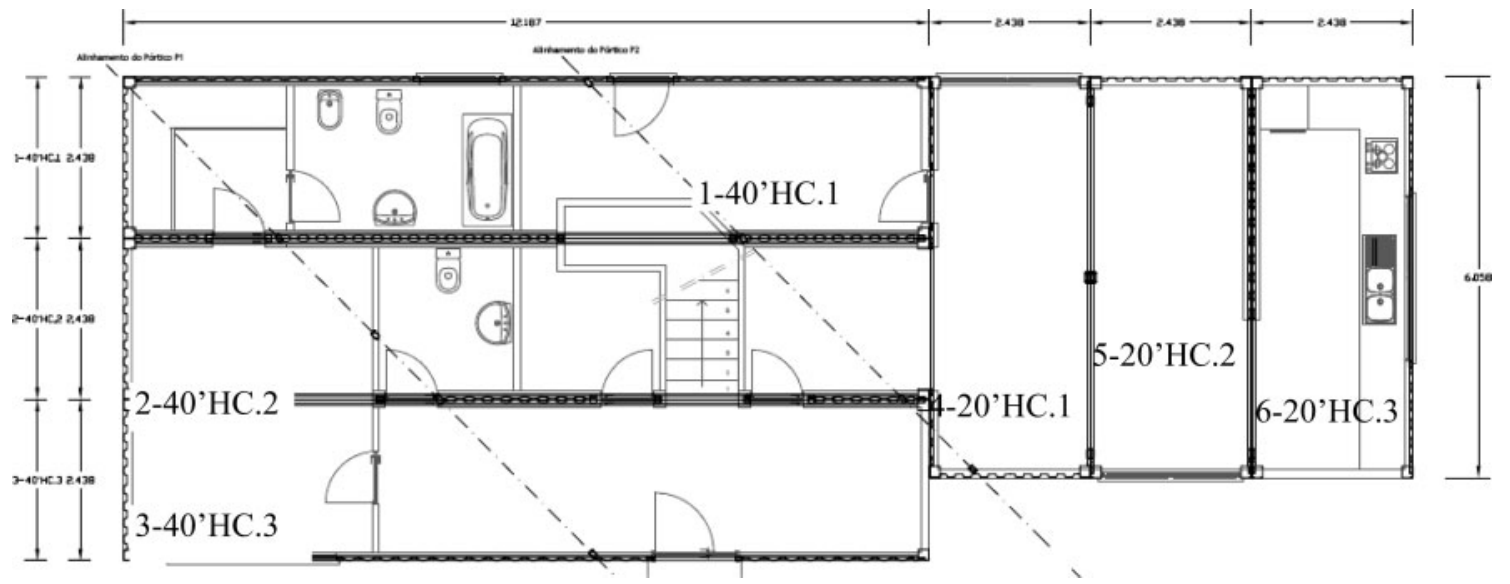

Fig. 12. Configuration: Floor 0
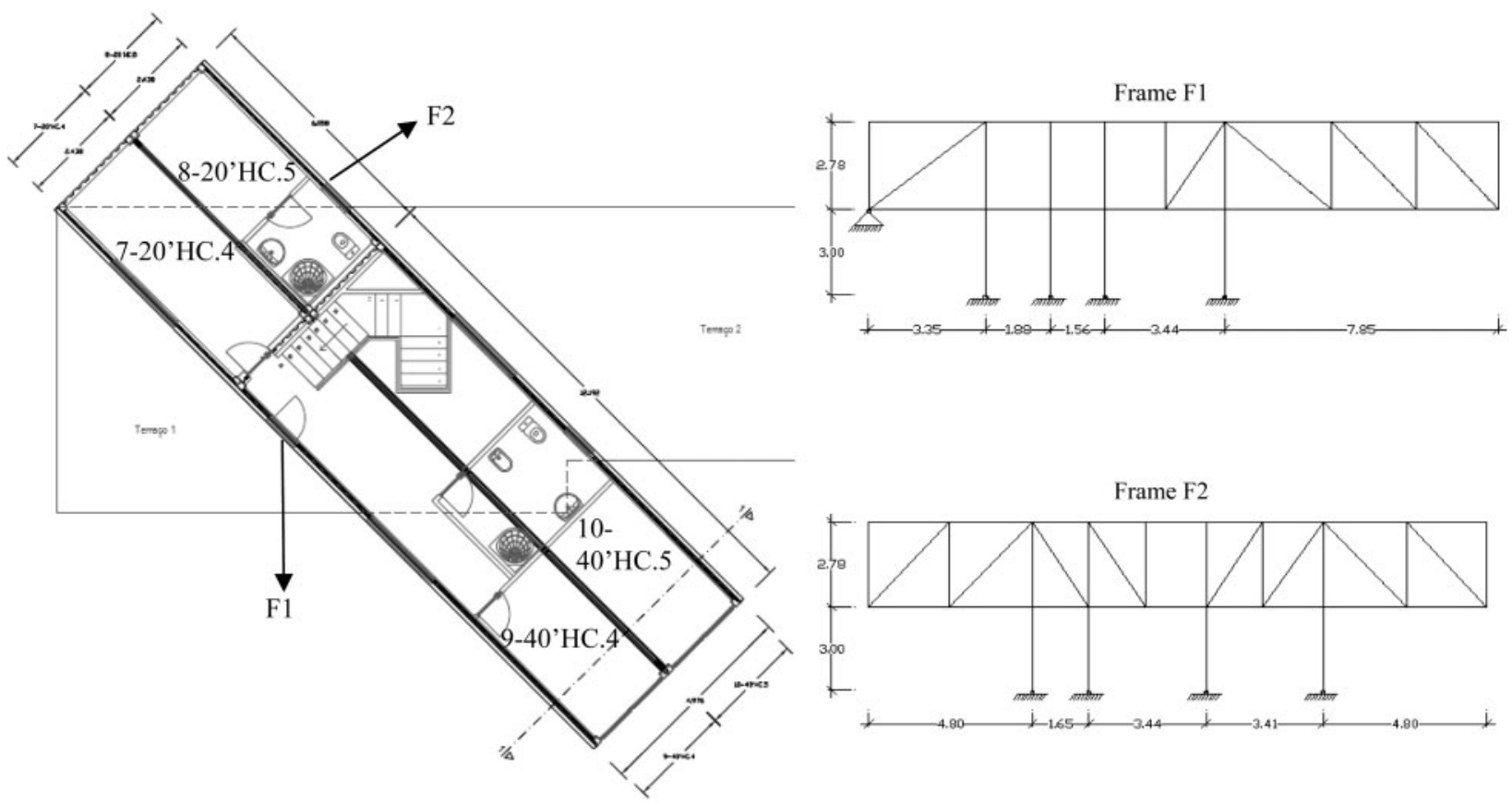

Fig. 13. Configuration with external trusses: Floor 1
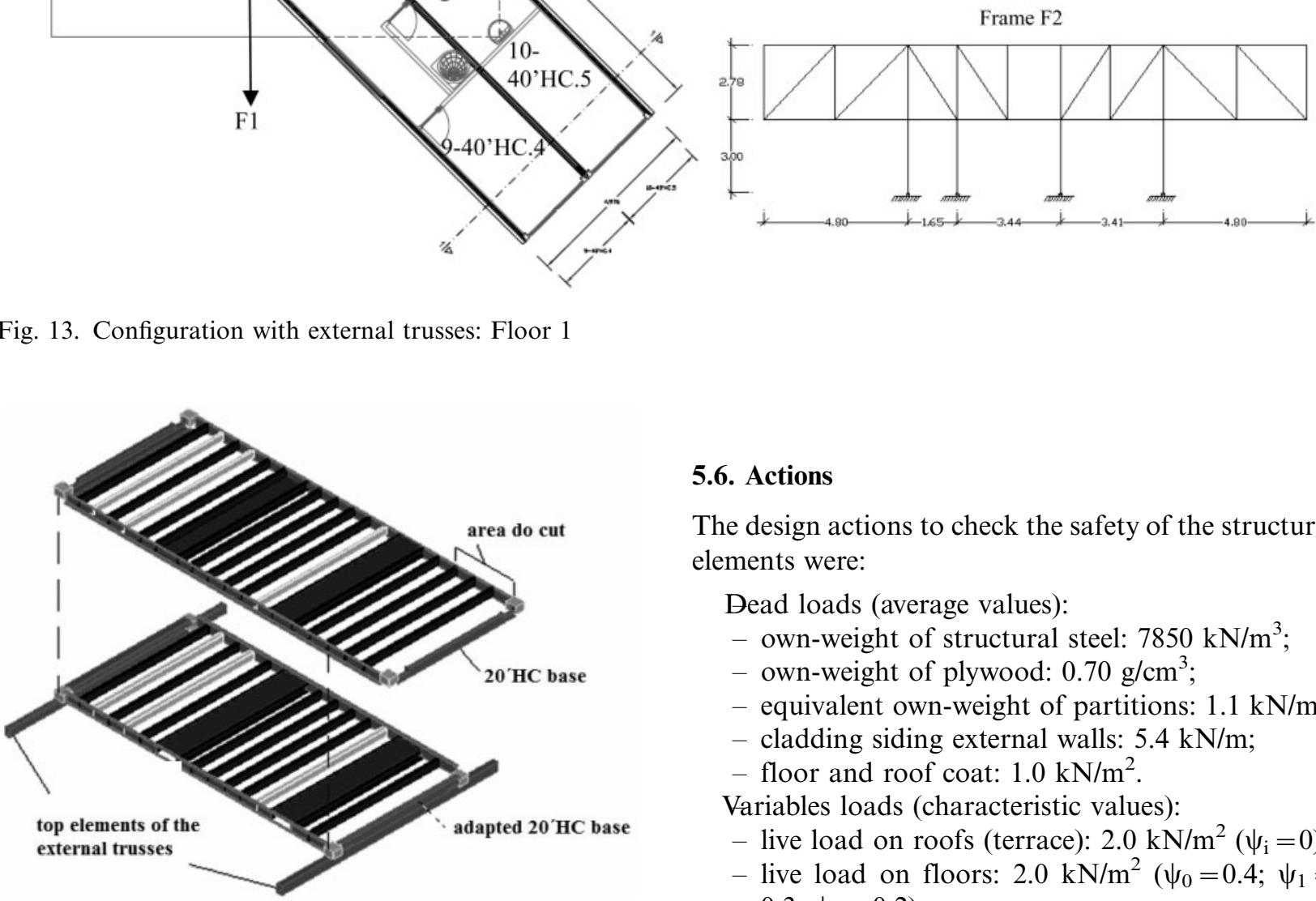

Fig. 14. Adaptation of base structures for the roofs

\subsection{Actions}

The design actions to check the safety of the structural elements were:

Bead loads (average values):

- own-weight of structural steel: $7850 \mathrm{kN} / \mathrm{m}^{3}$;

- own-weight of plywood: $0.70 \mathrm{~g} / \mathrm{cm}^{3}$;

- equivalent own-weight of partitions: $1.1 \mathrm{kN} / \mathrm{m}^{2}$;

- cladding siding external walls: $5.4 \mathrm{kN} / \mathrm{m}$;

- floor and roof coat: $1.0 \mathrm{kN} / \mathrm{m}^{2}$.

Variables loads (characteristic values):

- live load on roofs (terrace): $2.0 \mathrm{kN} / \mathrm{m}^{2}\left(\psi_{\mathrm{i}}=0\right)$;

- live load on floors: $2.0 \mathrm{kN} / \mathrm{m}^{2}\left(\psi_{0}=0.4 ; \psi_{1}=\right.$ $\left.0.3 ; \psi_{2}=0.2\right)$;

- snow: $1.7 \mathrm{kN} / \mathrm{m}^{2}\left(\psi_{0}=0.6 ; \psi_{1}=0.3 ; \psi_{2}=0\right)$; 


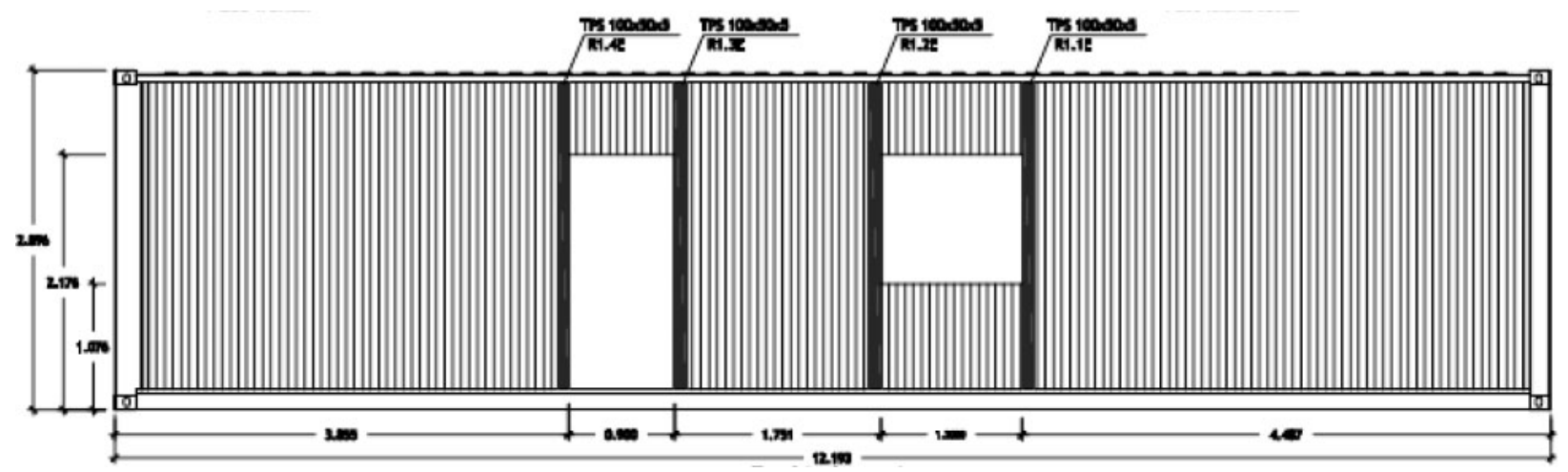

Fig. 15. Preparation of the container 1-40'HC.1
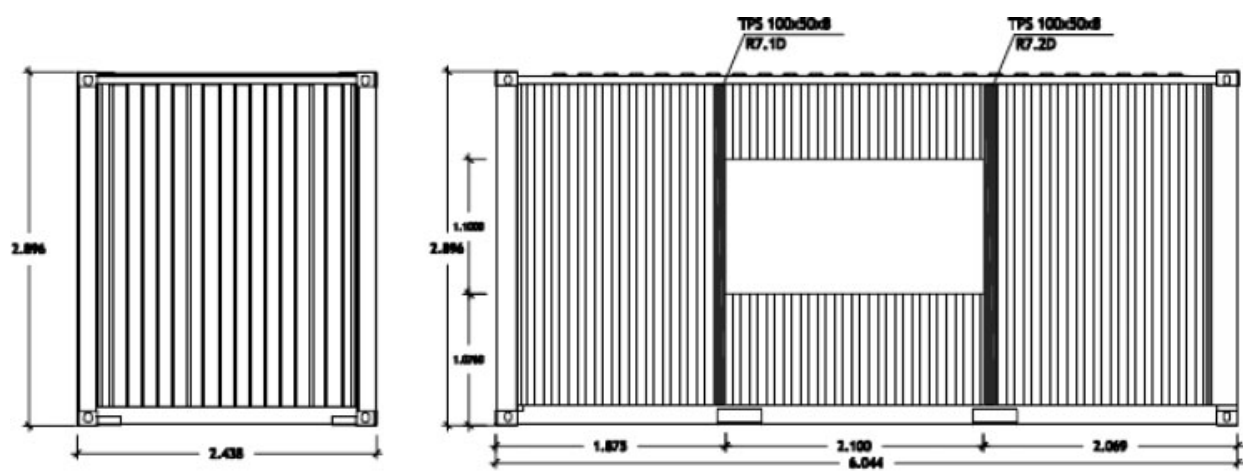

Fig. 16. Preparation of the container 6-20'HC.3

Table 10. Refurbishment of containers

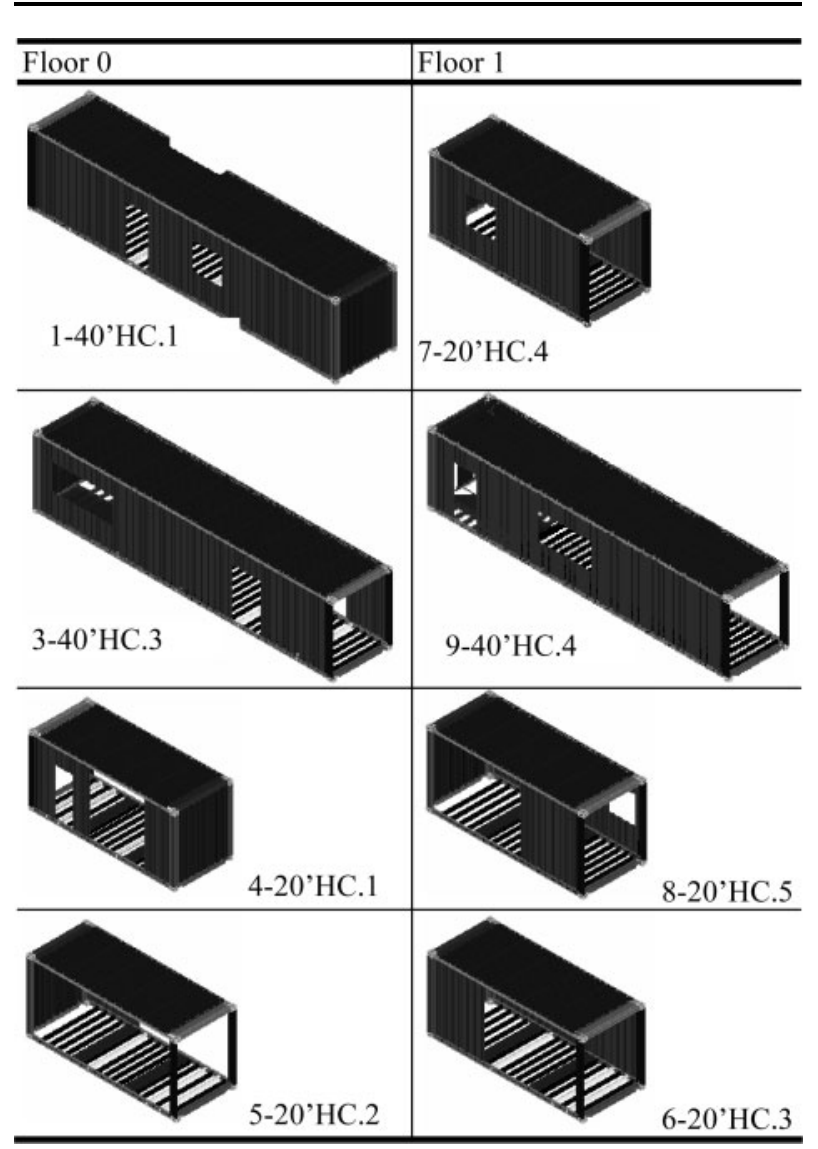

- earthquake: based on a dynamic analysis with response spectrum seismic loading $\left(\psi_{\mathrm{i}}=0\right)(\mathrm{Chu}$ et al. 2011).

To check safety for the ULS, fundamental and seismic combination of actions were applied (Eurocode 2001). To check the deformation for the SLS, quasi-permanent combination of actions was used (Eurocode 2001).

\subsection{Criteria's for ultimate limit states}

To check safety of cold-formed steel profiles, Eurocode 3 Part 1-3 (2004) was used. For commercial

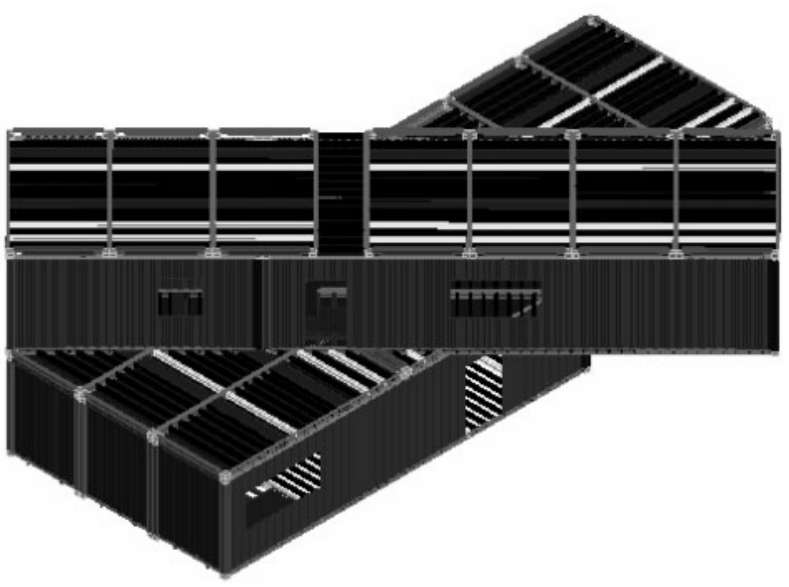

Fig. 17. Assembly of containers (overview) 


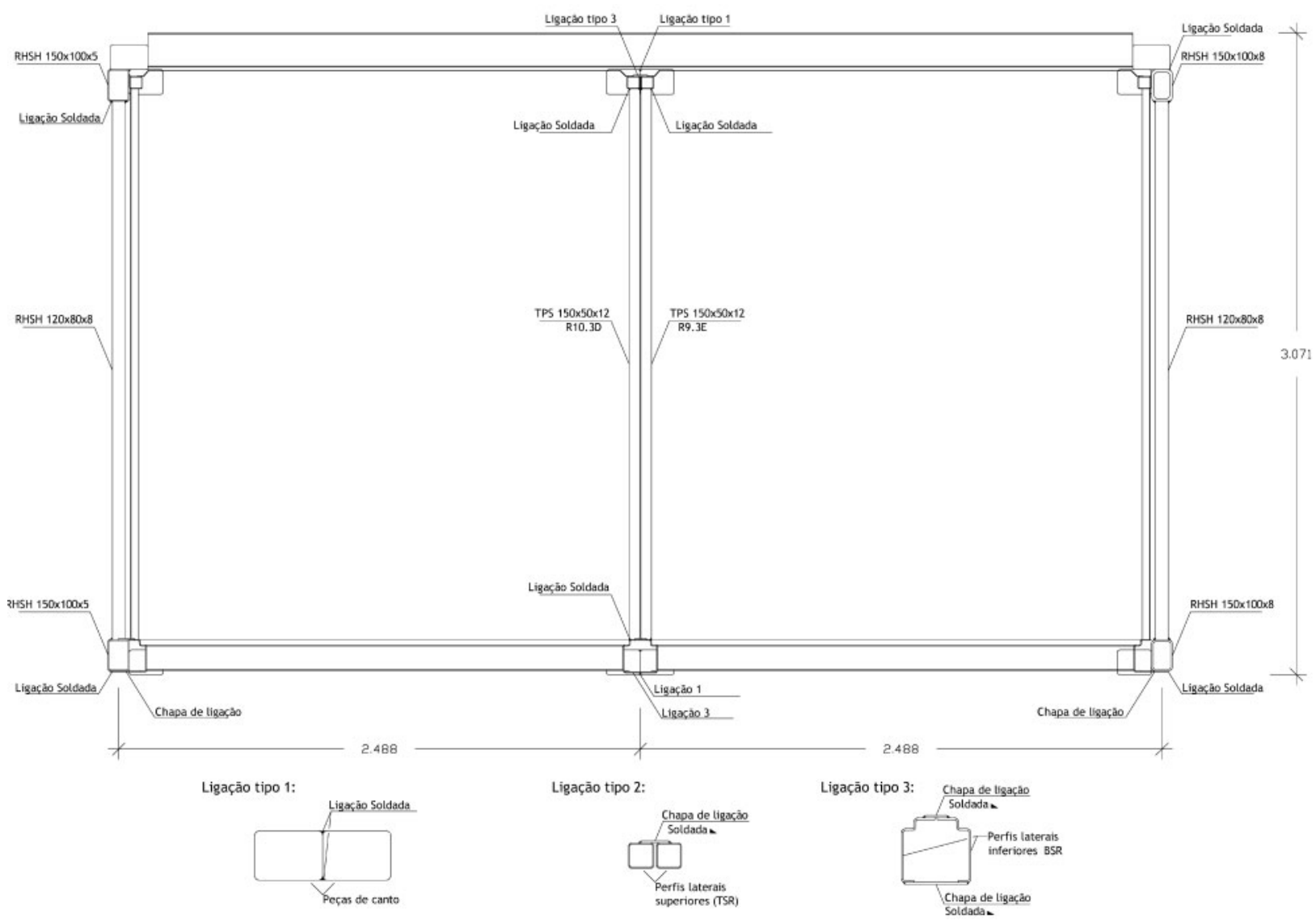

Fig. 18. Welding connections (transversal sections)

hot-rolled steel profiles, procedures of Eurocode 3 Part 1-1 (2006) were used.

The following ultimate limit states were checked: tension force, compression force, bending moment, shear force, compound bending, interaction between internal forces, and resistance to lateral buckling.

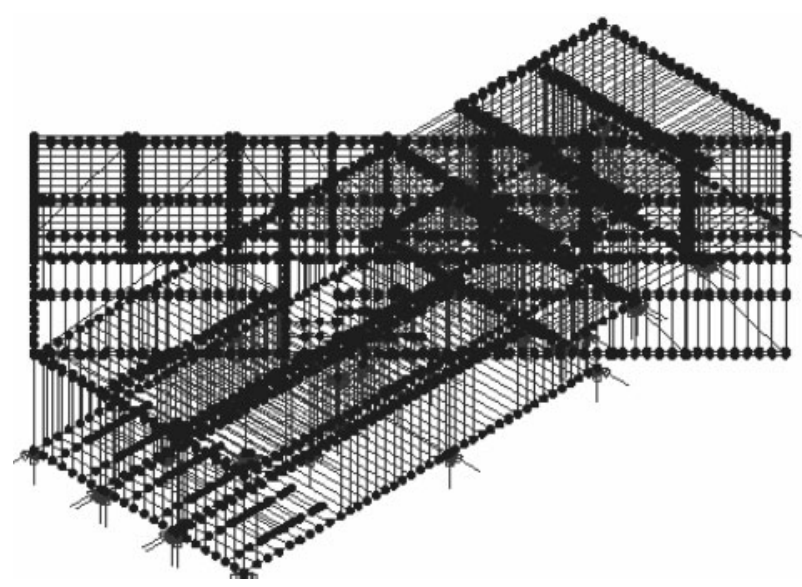

Fig. 19. Overview of the global numerical model
To check the safety of the sections for the bending moments (Ultimate Limit State), additional moments were added due to the eccentricity of the barycentre due to the reduction of the section in order to take into account for local buckling, as specified in Eurocode 3 (2004).

To check the resistance to lateral buckling, it is necessary to compute the resistance to buckling (bending moment): $M_{b, R d}$. This resistance depends on the elastic critical moment for lateral buckling, which in turn depends on unknown parameters for many of the noncommercial sections under analysis. In fact some of these parameters, such as warping inertia, are obtained from experimental studies. Then, it is not easy to check buckling for many profiles being in study. In accordance with Clause 6.3.2.1 (2) of Eurocode 3 Part 1-1 (2006), profiles with sufficient lateral bracing are not susceptible to lateral buckling. Thus, to overcome the problem mentioned above, profiles should be braced in order that buckling verification do not need to be carried out. In fact, for many elements such condition is already satisfied due to the connection to other elements. 
Table 11. Design strengths for profiles (gross sections)

\begin{tabular}{|c|c|c|c|c|c|c|c|}
\hline Profile & $N_{R d}(\mathrm{kN})$ & $M_{R d . y}(\mathrm{KN} \mathrm{m})$ & $M_{R d . z}(\mathrm{KN} \mathrm{m})$ & $V_{w . R d . z}(\mathrm{kN})$ & $V_{b . R d . z}(\mathrm{kN})$ & $V_{w . R d . y}(\mathrm{kN})$ & $V_{b . R d . y}(\mathrm{kN})$ \\
\hline DCP & 1188.8 & 14.98 & 36.98 & 73.79 & 59.10 & 429.71 & - \\
\hline $\mathrm{FH}^{20} \mathrm{HC}$ & 206.06 & 3.65 & 3.65 & 52.09 & 46.00 & - & - \\
\hline $\mathrm{FS}^{40} \mathrm{HC}$ & 206.06 & 3.65 & 3.65 & 52.09 & 34.30 & - & - \\
\hline $\mathrm{TSR}^{20} \mathrm{HC}$ & 206.06 & 3.65 & 3.65 & 52.09 & 56.00 & - & - \\
\hline $\mathrm{TSR}^{40} \mathrm{HC}$ & 206.06 & 3.65 & 3.65 & 52.09 & 56.00 & - & - \\
\hline $\mathrm{FS}^{20} \mathrm{HC}$ & 393.76 & 12.38 & 4.57 & 41.23 & 41.00 & 37.62 & 32.50 \\
\hline FCP & 929.25 & 27.51 & 29.75 & 196.41 & 126.00 & 222.45 & 193.00 \\
\hline $\mathrm{BSR}^{40^{\prime} \mathrm{HC}}$ & 342.95 & 11.21 & 2.66 & 111.50 & 113.80 & - & - \\
\hline $\mathrm{BSR}^{20} \mathrm{HC}$ & 316.00 & 11.83 & 1.07 & 117.19 & 104.25 & - & - \\
\hline BCM1 & 248.02 & 8.55 & 1.33 & 76.68 & 70.67 & - & - \\
\hline BCM3 & 242.41 & 0.46 & 4.64 & - & - & - & - \\
\hline BCM4 & 191.12 & 8.11 & 1.32 & 73.43 & 74.20 & - & - \\
\hline
\end{tabular}

Table 12. Design strengths for profiles (effective sections)

\begin{tabular}{|c|c|c|c|c|c|c|c|c|c|c|}
\hline Profile & $N_{t . R d}(\mathrm{kN})$ & $N_{c . R d}(\mathrm{kN})$ & $\begin{array}{l}M_{c . R d . y} \\
(\mathrm{kN} \mathrm{m})\end{array}$ & $\begin{array}{l}M_{c . R d . z} \\
(\mathrm{kN} \mathrm{m})\end{array}$ & $e_{N y}(\mathrm{~mm})$ & $e_{N z}(\mathrm{~mm})$ & $V_{w . R d . z}(\mathrm{kN})$ & $V_{b . R d . z}(\mathrm{kN})$ & $\begin{array}{c}V_{w \cdot R d \cdot y} \\
(\mathrm{kN})\end{array}$ & $V_{b . R d . y}(\mathrm{kN})$ \\
\hline DS & 531.4 & 522.5 & 16.27 & 11.93 & 0.2 & 1.5 & 118.0 & 92.5 & 157.5 & 140 \\
\hline $\mathrm{DH}^{40 \prime \mathrm{HC}}$ & 795.6 & 612.4 & 19.29 & 14.52 & 40.9 & 10.7 & 146.1 & 90.3 & 147.6 & 0 \\
\hline $\mathrm{DH}^{20 \prime H C}$ & 802.4 & 587.1 & 21.36 & 13.82 & 57.0 & 11.9 & 147.6 & 136.0 & 172.9 & 127 \\
\hline $\mathrm{FH}^{40^{\prime} \mathrm{HC}}$ & 537.4 & 236.3 & 6.27 & 2.52 & 94.1 & 20.6 & 51.4 & 60.0 & 72.1 & 46.3 \\
\hline BCM2 & 285.4 & 260.9 & 8.83 & 1.51 & 4.5 & 4.8 & 76.7 & 113.0 & - & - \\
\hline BCM5 & 279.8 & 255.3 & 8.37 & 1.50 & 4.5 & 4.7 & 73.4 & - & - & - \\
\hline BCM6 & 536.6 & 510.8 & 17.11 & 9.41 & 1.4 & 4.3 & 119.2 & 99.0 & - & - \\
\hline FP & 995.5 & 414.4 & 15.44 & 184.7 & - & - & 153.4 & 93.0 & - & - \\
\hline
\end{tabular}

Table 13. Design strengths for sheets

\begin{tabular}{|c|c|c|c|c|c|}
\hline Sheet & $N_{t . R d}(\mathrm{kN} / \mathrm{m})$ & $N_{c . R d}(\mathrm{kN} / \mathrm{m})$ & $M_{R d . z}(\mathrm{kN} \mathrm{m} / \mathrm{m})$ & $V_{w \cdot R d}(\mathrm{kN} / \mathrm{m})$ & $V_{b . R d}(\mathrm{kN} / \mathrm{m})$ \\
\hline Few & 761.79 & 588.32 & 98.55 & 61.62 & 60.66 \\
\hline $\mathrm{SW}_{1 / 3}{ }^{4} \mathrm{HC}$ & 659.52 & 594.35 & - & - & - \\
\hline $\mathrm{sw}_{1 / 3} 2{ }^{\prime} \mathrm{HC}$ & 659.88 & 622.01 & - & - & - \\
\hline $\mathrm{sw}_{2}{ }^{40} \mathrm{HC}$ & 528.26 & 391.12 & - & - & - \\
\hline $\mathrm{sw}_{2}^{20 \prime \mathrm{HC}}$ & 528.42 & 411.87 & - & - & - \\
\hline
\end{tabular}

\subsection{Design resistances and safety verification}

This section summarizes the verifications carried out only for the elements that compose the containers. For the strengthening profiles and for the profiles that compose external trusses, being current commercial sections the verification was based on Eurocode 3 Part 1-1 (2006). Such verifications are not summarized here.

Table 11 summarizes the values for the design strengths of the profiles based on gross section (profiles for which effective section was not calculated). Table 12 summarizes the values for the design strengths of the profiles based on effective section.
Table 13 summarizes the values for the design strengths of sheets. The front face sheets present bending moment around $z$ and axial force. The other sheets present essentially axial force.

From a comparative analysis between design internal forces for the several combinations (the several quantity of values are not presented here) and design strengths on the critical sections of the elements that compose the containers, it was possible to list several elements that did not verify safety (Table 14). The problems are mainly associated with compoundbending verification. Thus, it was necessary to provide 
Table 14. Profiles with insufficient resistance

\begin{tabular}{|c|c|}
\hline Profile & Localization \\
\hline $\mathrm{TSR}^{20} \mathrm{HC}$ & 6-20’HC.3 \\
\hline \multirow[t]{5}{*}{$\mathrm{TSR}^{40^{\prime} \mathrm{HC}}$} & 1-40’HC.1 \\
\hline & 2-40’НС. 2 \\
\hline & 2-40’НC. 2 \\
\hline & 3-40’HC.3 \\
\hline & 3-40’HC. 3 \\
\hline \multirow[t]{2}{*}{ FCP } & 1-40’HC.1 \\
\hline & 2-40’HC. 2 \\
\hline BCM6 & 2-20’НC. 2 \\
\hline \multirow{6}{*}{$\mathrm{BSR}^{40^{\prime} \mathrm{HC}}$} & 3-40’HC.3 \\
\hline & 1-40’НC.1 \\
\hline & 1-40’HC.1 \\
\hline & 2-40’HC. 2 \\
\hline & 3-40’НC.3 \\
\hline & 2-40’НC. 2 \\
\hline \multirow[t]{4}{*}{$\mathrm{BSR}^{20^{\prime} \mathrm{HC}}$} & 6-20’HC.3 \\
\hline & 5-20’HC. 2 \\
\hline & 4-20’HC.1 \\
\hline & 8-20’HC.5 \\
\hline
\end{tabular}

additional strengthening elements (RHSH profiles) to solve these problems.

\section{Conclusions}

The transposition of code procedures suited for current steel building structures to verify the safety of the elements that compose the shipping containers is possible, but some verifications are not easily carried out due to the lack of some important geometrical properties (for instance, buckling verification). This problem appears because it is necessary to analyze noncommercial cold-formed steel profiles which are not parameterized for the application of code procedures. The application of the structural codes for this constructive system requires the assumption of several simplifications for the calculation model and for the verifications, and also the adoption of construction details in order to impose a behavior to the components to bring them closer to the assumed simplified calculation model.

Moreover, the shipping containers are composed of several steel elements. The majority of the noncommercial sections are classified as Class 4. For these elements, effective sections must be computed to take into account the effect of local buckling. The calculation of the geometrical properties of these sections is a lengthy and complex process.

This study shows that the calculation of structural projects with this construction system by using the resources currently available for the structural engineer (structural codes) is not easy. The required calculations, the lack of tabulated values for the geometrical characteristics of the noncommercial steel profiles that compose the shipping containers and the lack of experience about the structural global and local behavior of shipping containers are some negative aspects to have into account. Moreover, it should be noted that there are several shipping containers models on the market.

Nevertheless, this study shows that the feasibility of this construction system, based on the use of refurbished shipping containers as construction modules for buildings, should be recognized.

\section{References}

Chu, Y.-P.; Yao, Y.; Deng, Y.-J. 2011. Seismic behavior analysis on the cold-formed in modular house, Advanced Materials Research 150-151: 512-516. http://dx.doi.org/10.4028/www.scientific.net/AMR.225226.512

Davies, J. M. 2000. Recent research advances in cold-formed steel structure, Journal of Constructional Steel Research 55(1-3): 267-288. http://dx.doi.org/10.1016/S0143-974X(99)00089-9

Eurocode. 2001. Basis of structural design. Brussels: CEN European Committee of Standardization. 88 p.

Eurocode 3. 2003. Design of steel structures. Part 1-5: plated structural elements. Brussels: CEN - European Committee of Standardization. $53 \mathrm{p}$.

Eurocode 3. 2004. Design of steel structures. Part 1-3: general rules. Supplementary rules for cold-formed members and sheeting. Brussels: CEN - European Committee of Standardization. 125 p.

Eurocode 3. 2006. Design of steel structures. Part 1-1: general rules and rules for buildings. Brussels: CEN European Committee of Standardization. 116 p.

ISBU (Intermodal Steel Building Units and Containers Homes). 2009. ISO shipping container specifications/ materials. Cheyenne, WY: ISBU Association.

ISO 1496-1:1990. Series 1 - container shipping. Specifcation and testing - part 1: containers for marine applications in use. Geneva, Switzerland: International Organization for Standardization. $24 \mathrm{p}$.

ISO 668:1995. Series 1 - container shipping. Classification, dimensions and calculations. Geneva, Switzerland: International Organization for Standardization. 6 p.

ISO 3874:1997. Series 1 - container shipping. Handling and safety. Geneva, Switzerland: International Organization for Standardization. $29 \mathrm{p}$.

ISO 830:1999. Freight containers - vocabulary. Geneva, Switzerland: International Organization for Standardization. 40 p.

Johansson, B.; Maquoi, R.; Sedlacek, G. 2001. New design rules for plated structures in Eurocode 3, Journal of Constructional Steel Research 57(3): 279-311. http://dx.doi.org/10.1016/S0143-974X(00)00020-1

Lun, Y. H. V. 2011. Green management practices and firm performance: a case of container terminal, Resources, Conservation and Recycling 55(6): 559-566. http://dx.doi.org/10.1016/j.resconrec.2010.12.001 
LUSAS. 2010. Lusas finite element system, version 14.3. Kingston-upon-Thames, England: FEA - Finite Element Analysis Ltd.

Murdock, J. 2009. Now shipping to a site near you: cargo container offices, Architectural Record 197(10): 34.

Nunes, N. C. G. 2009. Exploitation of shipping containers for housing: Master Thesis, University of Beira Interior, Portugal (in Portuguese).

Pisinger, D. 2002. Heuristics for the container loading problem, European Journal of Operational Research 141(2): $382-392$.

http://dx.doi.org/10.1016/S0377-2217(02)00132-7
Rondal, J. 2000. Cold-formed steel members and structures: general report, Journal of Constructional Steel Research 55(1-3): 155-158. http://dx.doi.org/10.1016/S0143-974X(99)00083-8

Vijayalaxmi, J. 2010. Towards sustainable architecture - a case with Greentainer, Local Environment: The International Journal of Justice 15(3): 245-259. http://dx.doi.org/10.1080/13549830903575596

Webb, M. 2006. Container art: Shigeru Ban's inventive yet frugal nomadic museum berths on the Santa Monica Beachfront, Architectural Review 219(1311): 48-53.

Luís F. A. BERNARDO. Assistant Professor at the Department of Civil Engineering and Architecture of the University of Beira Interior, Portugal. He is a member of the research Centre C-made: Centre of Materials and Building Technologies, Portugal. His research interests include the mechanical behavior of structural concrete and the development of new structural materials and building systems.

Luiz A. P. de OLIVEIRA. Associate Professor at the Department of Civil Engineering and Architecture of the University of Beira Interior, Portugal. He is a member of the research Centre C-made: Centre of Materials and Building Technologies, Portugal. He is a member of CIB-W115 Commission, Construction Materials Stewardship. His research interests include the technology of concrete and masonry structures, particularly the composites rheological behavior and hi-value wastes materials and components.

Miguel C. S. NEPOMUCENO. Assistant Professor in Construction at the Department of Civil Engineering and Architecture of the University of Beira Interior, Portugal. He is a member of the research Centre C-made: Centre of Materials and Building Technologies, Portugal. His research interests include the construction materials, particularly the cement based materials. His research interests include also building physics, indoor environment and building systems.

Jorge M. A. ANDRADE. Assistant Professor at the Department of Civil Engineering and Architecture of the University of Beira Interior, Portugal. He is a member of the research Centre C-made: Centre of Materials and Building Technologies, Portugal. His research interests include the behavior of steel, aluminum, and reinforced concrete structural elements, mainly numerical simulations of problems. 